\title{
Targeting c-IAP1, c-IAP2, and Bcl-2 Eliminates Senescent Glioblastoma Cells Following Temozolomide Treatment
}

\author{
Christian Schwarzenbach (1), Larissa Tatsch, Juliana Brandstetter Vilar, Birgit Rasenberger, Lea Beltzig, \\ Bernd Kaina (D), Maja T. Tomicic *(1) and Markus Christmann *(D)
}

check for updates

Citation: Schwarzenbach, C.;

Tatsch, L.; Brandstetter Vilar, J.;

Rasenberger, B.; Beltzig, L.; Kaina, B.; Tomicic, M.T.; Christmann, M.

Targeting c-IAP1, c-IAP2, and Bcl-2 Eliminates Senescent Glioblastoma

Cells Following Temozolomide

Treatment. Cancers 2021, 13, 3585.

https://doi.org/10.3390/

cancers 13143585

Academic Editors: Donat Kögel,

Christel Herold-Mende and

Benedikt Linder

Received: 15 June 2021

Accepted: 14 July 2021

Published: 17 July 2021

Publisher's Note: MDPI stays neutral with regard to jurisdictional claims in published maps and institutional affiliations.

Copyright: (c) 2021 by the authors. Licensee MDPI, Basel, Switzerland. This article is an open access article distributed under the terms and conditions of the Creative Commons Attribution (CC BY) license (https:/ / creativecommons.org/licenses/by/ $4.0 /)$.
Department of Toxicology, University Medical Center, Obere Zahlbacher Str. 67, D-55131 Mainz, Germany; schwarzenbach@uni-mainz.de (C.S.); latatsch@uni-mainz.de (L.T.); jbrandst@uni-mainz.de (J.B.V.); rasebi00@uni-mainz.de (B.R.); lea.beltzig@uni-mainz.de (L.B.); kaina@uni-mainz.de (B.K.)

* Correspondence: tomicic@uni-mainz.de (M.T.T.); mchristm@uni-mainz.de (M.C.)

Simple Summary: Despite extensive research, malignant glioma remains the most aggressive and fatal type of brain tumor. Following resection, therapy is based on radiation concomitant with the methylating agent temozolomide (TMZ), followed by adjuvant high-dose TMZ. In previous work, we showed that following TMZ exposure, most glioma cells evade apoptosis and enter a senescent state and are thereby protected against anticancer therapy. Senescent cells may escape from senescence, contributing to the formation of recurrences or can induce the senescence-associated secretory phenotype (SASP), which may impact therapy success. Therefore, direct targeting of senescent cells might be favorable to improve the effect of TMZ-based anticancer therapy. Here we show that during TMZ-induced senescence in glioblastoma cells, the antiapoptotic factors c-IAP2 and Bcl-2 are responsible for the prevention of cell death and that inhibition of these factors by BV6 and venetoclax effectively kills senescent glioblastoma cells.

Abstract: Therapy of malignant glioma depends on the induction of $\mathrm{O}^{6}$-methylguanine by the methylating agent temozolomide (TMZ). However, following TMZ exposure, most glioma cells evade apoptosis and become senescent and are thereby protected against further anticancer therapy. This protection is thought to be dependent on the senescent cell anti-apoptotic pathway (SCAP). Here we analyzed the factors involved in the SCAP upon exposure to TMZ in glioblastoma cell lines (LN-229, A172, U87MG) and examined whether inhibition of these factors could enhance TMZ-based toxicity by targeting senescent cells. We observed that following TMZ treatment, c-IAP2 and Bcl-2 were upregulated. Inhibition of these SCAP factors using non-toxic concentrations of the small molecule inhibitors, BV6 and venetoclax, significantly increased cell death, as measured $144 \mathrm{~h}$ after TMZ exposure. Most importantly, BV6 and venetoclax treatment of senescent cells strongly increased cell death after an additional $120 \mathrm{~h}$. Moreover, Combenefit analyses revealed a significant synergy combining BV6 and venetoclax. In contrast to BV6 and venetoclax, AT406, embelin, and TMZ itself, teniposide and the PARP inhibitor pamiparib did not increase cell death in senescent cells. Based on these data, we suggest that BV6 and venetoclax act as senolytic agents in glioblastoma cells upon TMZ exposure.

Keywords: inhibitor of apoptosis (IAP); alkylating drugs; malignant glioma; senescence

\section{Introduction}

Among the different subtypes of brain cancer, glioblastomas (WHO grade IV) account for $\sim 60 \%$ of high-grade gliomas [1]. Despite intensive efforts, patients have a dismal prognosis of 14.6 months median survival and a 2-year survival rate of less than $26.5 \%$ [2]. The current treatment of glioblastomas consists of maximum safe resection followed by radiotherapy with concomitant and adjuvant temozolomide (TMZ) [3]. TMZ exerts its cytotoxic effect by the induction of $\mathrm{O}^{6} \mathrm{MeG}$, and subsequently by the formation of DNA 
double-strand breaks (DSBs), finally leading to apoptosis [4-6]. However, in addition to apoptosis, TMZ strongly induces senescence in glioma cells $[7,8]$.

Senescence was initially described as a permanent cell cycle arrest that limits the life span of cultured human fibroblasts [9]. Contrary to quiescence, which is defined as a temporary cell cycle arrest, senescence is not reversible in response to proliferative conditions (for review see [10-13]). In senescent cells, tumor-promoting and tumor-suppressing factors can be activated at the same time [14]. As a tumor-suppressing mechanism, the senescence-associated secretory phenotype (SASP), which is characterized by secretion of multiple immune factors, including interleukins, chemokines, growth factors, and matrix metalloproteinases [15-17], can reinforce the growth arrest by increasing ROS production and by enhancing the DNA damage response $[17,18]$. In addition, SASP induces an inflammatory response and activates immune cells, which eliminate senescent tumor cells $[19,20]$. On the other hand, SASP factors also act as potent tumor promoters, enhancing malignant tumorigenesis. Thus, the SASP can enhance the proliferation of neoplastic epithelial cells [21] and promote EMT [22,23] as well as tumor growth in vivo [24,25].

Several studies have indicated that cells can escape from genotoxin-induced senescence when the initial DNA damage stimuli are removed [26-29]. However, this matter is far from being resolved. Current knowledge suggests that senescence is highly dynamic and that an escape does not mediate a full conversion of the senescent phenotype back to the pre-senescent status [30]. In addition to well-established factors involved in cell cycle arrest, such as p53, p16, and $\mathrm{Rb}$, or downregulation of mTOR, epigenetic alterations are also highly important for senescence. Thus, it was shown that the demethylases JMJD2C and LSD1 mediate escape from oncogene-induced senescence [31] and that the H3K9 histone methyltransferase Suv39h1 is important for maintaining therapy-induced senescence [32]. Moreover, single-cell experiments showed that tumor cells can restart proliferation and in parallel still show $ß-G a l$ positivity [33]. Most importantly, it has been shown that oncogeneinduced senescence can be overcome in melanocytes, turning them into tumor-initiating cells [34]. If this also holds true for TMZ exposure in glioma cells, then these cells, which accumulated genomic alterations during senescence, could contribute to the formation of recurrences. Killing of these senescent cells would be desirable for two reasons: firstly, to prevent potential formation of recurrences from senescent cells, and secondly, to reduce negative effects on non-tumorigenic cells induced by SASP [35]. Agents that kill senescent cells are called "senolytics". Their discovery was based on the observation that senescent cells are resistant to apoptosis, due to upregulation of specific senescent cell anti-apoptotic pathways (SCAPs), which might be caused by senescence-associated mitochondrial dysfunction (SAMD) (for review see $[36,37]$ ).

Here, we analyzed whether the anti-apoptotic factors Bcl-2, Bcl-xL, c-IAP1, c-IAP2, XIAP, and Survivin play an essential role in the SCAPs induced by TMZ, and whether inhibition of these factors could enhance cytotoxicity by targeting senescent cells. Our data indicate that especially c-IAP2 and Bcl-2 play an important role in the TMZ-induced SCAPs. Thus, pharmacological inhibition of these factors strongly enhances cell death following TMZ and potentially improves the response of malignant glioma to TMZ-based therapy.

\section{Materials and Methods}

\subsection{Cell Culture and Drug Treatment}

The glioma cell lines LN-229 (RRID:CVCL_0393), A172 (RRID:CVCL_0131), and U87MG (RRID:CVCL_0022; since misidentified, it refers to as "glioblastoma of unknown origin") were cultivated in Dulbecco's minimal essential medium (DMEM) containing $10 \%$ fetal bovine serum (FBS) in a humidified atmosphere containing $5 \% \mathrm{CO}_{2}$ at $37^{\circ} \mathrm{C}$. A172 and U87MG cells were purchased from Cell Line Service (Eppelheim, Germany), and the glioblastoma cell line LN-229 was obtained from LGC Standards (Wesel am Rhein, Germany). All three cell lines are proficient for p53 and deficient for MGMT. Immortalized human astrocytes were a gift from Timothy A. Chan (Memorial Sloan-Kettering Cancer Center, New York) and were previously described [38]. hTERT-immortalized RPE-1 cells 
were provided by ATCC. Cells were cultured in Dulbecco's modified Eagle's medium (DMEM) plus 10\% FBS. Human colonic epithelial cells (HCEC) [39] were a gift from Prof. Jerry Shay (UT Southwestern Medical Center, Dallas) and cultured in RPMI with 5\% FBS, supplemented with $25 \mathrm{ng} / \mathrm{mL}$ EGF (PeproTech), $1 \mu \mathrm{g} / \mathrm{mL}$ hydrocortisone, $10 \mu \mathrm{g} / \mathrm{mL}$ insulin, $2 \mu \mathrm{g} / \mathrm{mL}$ transferrin (Sigma), and $50 \mu \mathrm{g} / \mathrm{mL}$ G418 (Sigma). The cell lines were kept in culture for max. two months and were regularly checked for mycoplasm contamination using the VenorGEM classic detection kit (\#11-1100) from Minerva Biologicals.

TMZ was a kind gift of Prof. Geoff Margison, Centre for Occupational and Environmental Health, University of Manchester, United Kingdom. It was solubilized in DMSO, diluted in distilled water immediately before use, and administeredat the indicated concentrations. BV6 (targets c-IAP1 and c-IAP2; CAS 1001600-56-1, Selleckchem), AT406 (targets c-IAP1 > XIAP; CAS 1071992-99-8, Selleckchem), venetoclax (targets Bcl-2; CAS 1257044-40-8, Selleckchem), and embelin (targets XIAP; CAS 550-24-3, Selleckchem) were solubilized in DMSO and used at the indicated concentrations.

\subsection{Preparation of $R N A, c D N A$ Synthesis, and Real Time $P C R$}

Total RNA was isolated using the Nucleo Spin RNA Kit (Machery and Nagel, Düren, Germany). One $\mu \mathrm{g}$ total RNA was transcribed into cDNA (Verso cDNA Kit, Thermo Scientific), and qPCR was performed using the GoTaq ${ }^{\circledR}$ qPCR Master Mix Protocol (Promega, Madison, USA) and the CFX96 Real-Time PCR Detection System (Biorad, München, Germany). In all experiments, PCR was performed in technical triplicates, and SEM showed intra-experimental variation. The analysis was performed using CFX Manager ${ }^{\mathrm{TM}}$ Software. Non-transcribed controls were included in each run, expression was normalized to GAPDH and ACTB, and the untreated control was set to one. The specific primers are listed in Table A1.

\subsection{Determination of Cell Death, Cell Cycle Progression, and Senescence}

For monitoring TMZ-induced apoptosis, attached and detached cells were collected, and annexin V-FITC/propidium iodide (PI) double stained cells were analyzed by flow cytometry. To determine cell death and cell cycle distribution, attached and detached cells were collected and stained with PI and analyzed by flow cytometry using BD FACSCanto II. Senescence was measured by SA- $\beta$-Gal staining and flow cytometry-based $C_{12}$ FDG staining in attached cells as described [40]. Experiments were repeated at least three times; mean values $\pm \mathrm{SD}$ are shown.

\subsection{Preparation of Protein Extracts and Western Blot Analysis}

Whole-cell and nuclear protein extracts were prepared as previously described [41]. Primary antibodies were diluted 1:500-1:1000 in 5\% BSA and 0.1\% Tween-TBS and incubated overnight at $4{ }^{\circ} \mathrm{C}$. Peroxidase-coupled secondary antibodies were diluted 1:2000 and incubated $2 \mathrm{~h}$ at RT. The protein-antibody complexes were visualized by Pierce ${ }^{\circledR}$ ECL Western Blotting Substrate (Thermo Fisher), and immunodetection was performed using the iBright CL1000 (Invitrogen) system. The specific antibodies are listed in Table A2.

\subsection{Quantification and Statistical Analyses}

The data were evaluated via Student's $t$-test and were expressed as mean $\pm \mathrm{SD}$. ${ }^{*} p \leq 0.01$ was considered statistically significant, ${ }^{* *} p \leq 0.01$ very significant and ${ }^{* * *} p \leq 0.001$ highly significant. Statistics were performed using GraphPad Prism version 6.01 for Windows, GraphPad Software, La Jolla California USA. Combenefit software version 2.021 was downloaded at https: / / sourceforge.net/projects/combenefit/, accessed on 20 June 2021 and used to perform surface analyses of drug combinations to identify Loewe synergy [42].

\section{Results}

\subsection{TMZ Induces Cell Death, Cell Cycle Arrest, and Senescence}

To identify SCAPs responsible for the resistance of senescent glioblastoma cells to TMZ, we initially used the MGMT-deficient and p53-proficient cell line LN-229. Exposure 
of LN-229 cells to $50 \mu \mathrm{M}$ TMZ showed a time-dependent induction of cell death, which however did not exceed 15\% within the first $144 \mathrm{~h}$ after treatment (Figure 1A). Cell death was executed by apoptosis and necrosis, as shown by annexinV / PI-staining (Figure 1B). Despite the low toxicity, clonogenic survival dropped $<20 \%$ at concentrations $\geq 2.5 \mu \mathrm{M}$ and was completely abolished at $50 \mu \mathrm{M}$ TMZ (Figure 1C), and more than $70 \%$ of the cells exhibited a senescent phenotype as determined by $\mathrm{C}_{12}$ FDG staining (Figure 1D). Importantly, higher TMZ concentrations $(100 \mu \mathrm{M})$ did not enhance cell death or the frequency of senescent cells. Upon TMZ exposure, senescence was associated with an accumulation of cells in the G2-phase and a strong formation of polyploid cells, indicating inaccurate cell division (Figure 1E,F).

It is important to note that even low concentrations of TMZ $(1-25 \mu \mathrm{M})$ induce a linear increase in the activation of the DNA damage response, cell death, and senescence $[43,44]$. However, the frequency of senescent cells was only $25 \%$ at $10 \mu \mathrm{M}$ and $35 \%$ at $25 \mu \mathrm{M} \mathrm{TMZ}$ (Figure A1A,B). The low amount of $\beta-$ Gal positive cells is presumably due to the fact that at low TMZ concentrations, a small number of cells was able to evade senescence, keeping their proliferating capacity, and form colonies at late times after TMZ treatment (144 h). Normally, measurement of senescent cells using $\beta$-Gal assay and $C_{12}$ FDG staining takes these colonies into account as separate cells. Thus, the clonogenic assay indicates how many cells are senescent at the time of analysis (e.g., $144 \mathrm{~h}$ ), but not at which frequency the cells enter senescence after TMZ treatment, thereby underestimating the senescence level. To take this into account, we re-analyzed the data, considering individual colonies as a single cell derived from a senescence-evading cell (Figure A1C,D).

Using this approach, the estimated senescence level was significantly higher. This further indicates that, upon treatment with low TMZ concentrations, induction of senescence is the predominant trait in TMZ-exposed cells. It is conceivable that at late time points, which have to be chosen in order to assess SCAPs and identify potential senolytics, already a low frequency of senescence-evading cells would overgrow the senescent population. To omit bias caused by senescence-evading cells, a concentration of $50 \mu \mathrm{M}$ TMZ was chosen for further experiments.
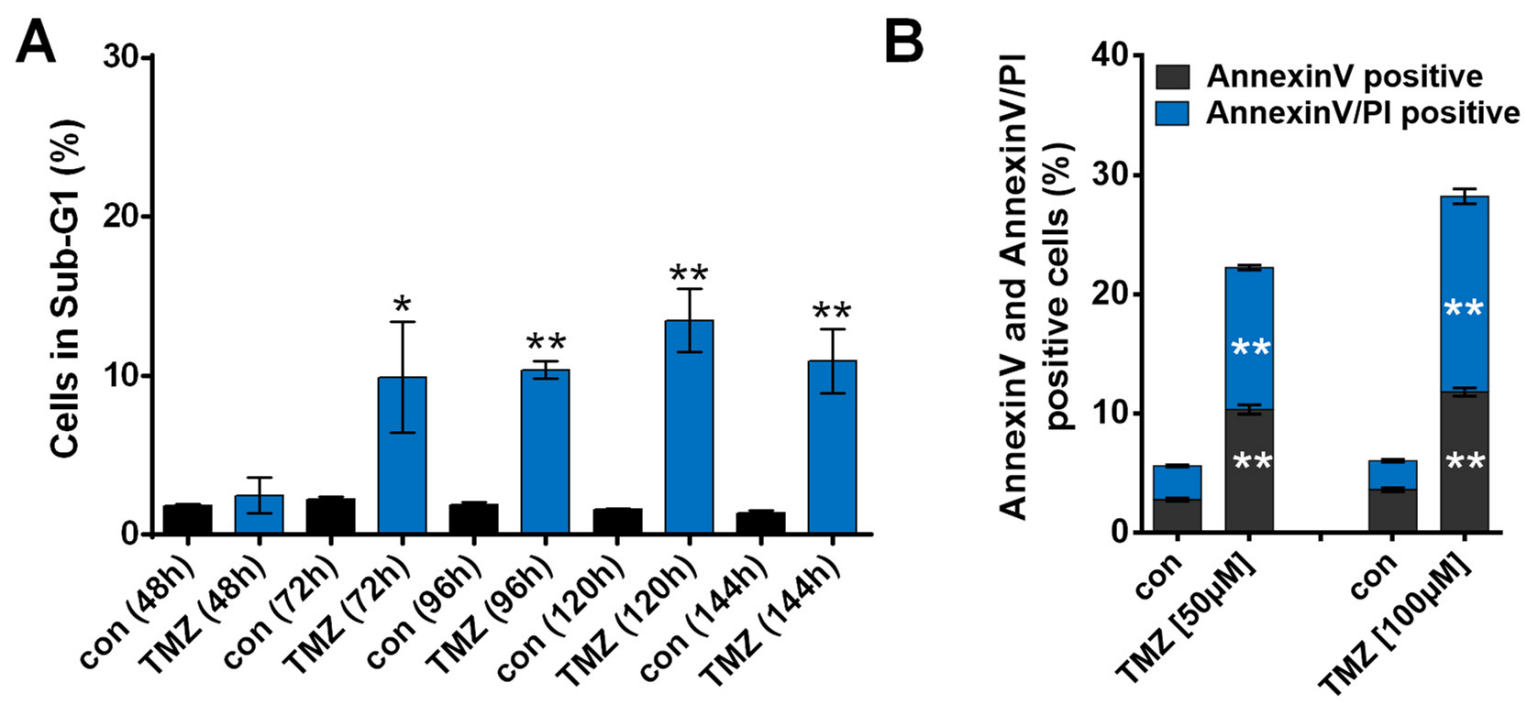

Figure 1. Cont. 

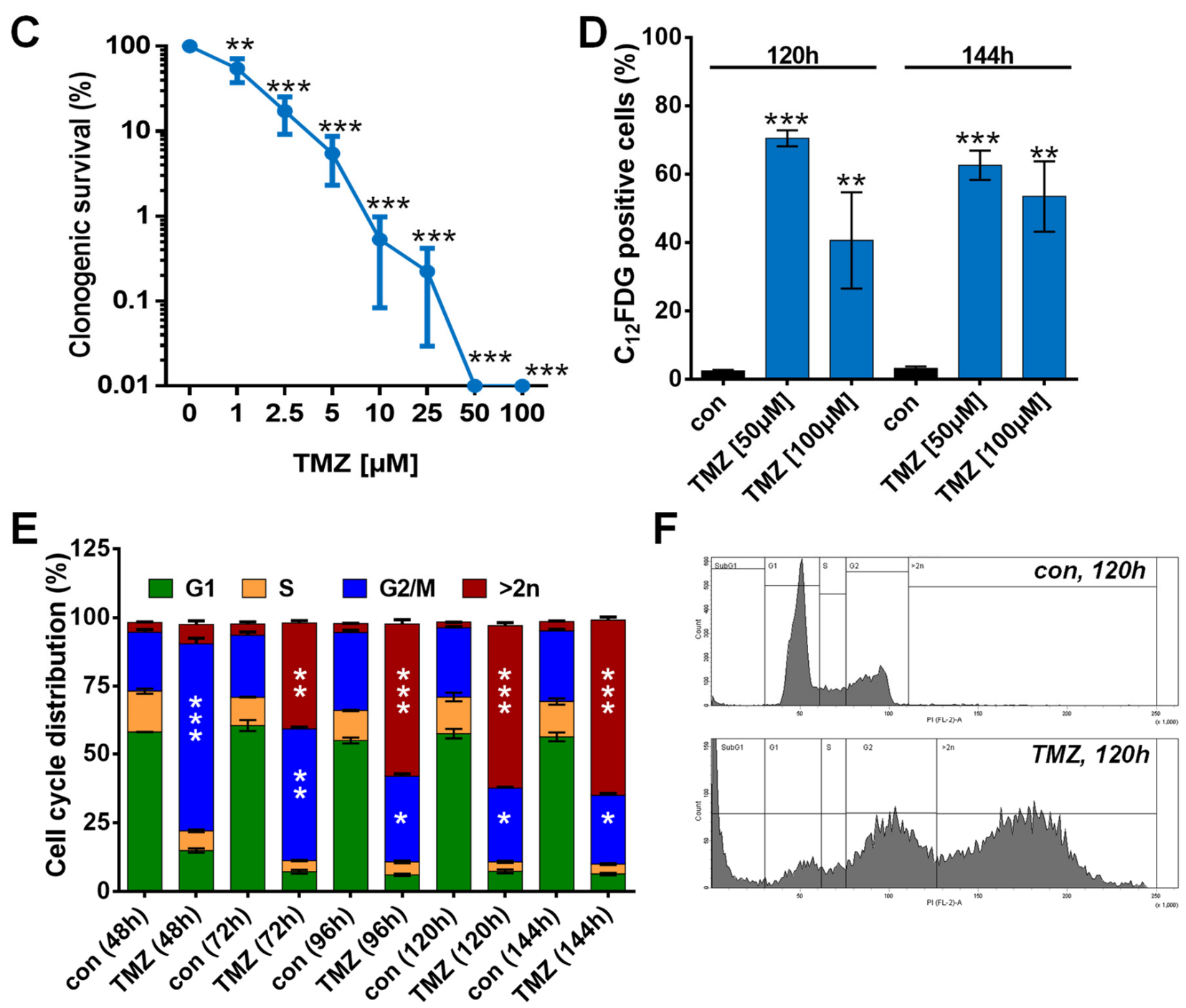

Figure 1. (A) Cell death was measured 48 to $144 \mathrm{~h}$ upon exposure to $50 \mu \mathrm{M}$ TMZ by flow cytometry using PI staining in LN-229 cells. (B) Cell death was measured 120 and $144 \mathrm{~h}$ upon exposure to $50 \mu \mathrm{M}$ TMZ by flow cytometry using Annexin V/PI staining in LN-229 cells. (C) Proliferation arrest was measured upon exposure up to $100 \mu \mathrm{M}$ TMZ by colony formation assay (CFA). (D) Senescence was measured by flow cytometry using $\mathrm{C}_{12}$ FDG staining 120 and $144 \mathrm{~h}$ after exposure to 50 or $100 \mu \mathrm{M}$ TMZ. (E) Cell cycle distribution was measured 48 to $144 \mathrm{~h}$ upon exposure to $50 \mu \mathrm{M}$ TMZ by flow cytometry using PI staining in LN-229 cells. (F) Representative histograms showing the appearance of cells harboring $>2 \mathrm{n}$ DNA $120 \mathrm{~h}$ after TMZ $(50 \mu \mathrm{M})$ exposure. (A-E) Experiments were performed in triplicate, and differences between treatment and control were statistically analyzed using Student's $t$-test (not labeled $=$ not significant, ${ }^{*} p<0.1,{ }^{* *} p<0.01,{ }^{* * *} p<0.001$ ). Concerning cell cycle distribution, at all the time points, a significant $\left.{ }^{* * *}\right)$ decrease of cells in G1 phase was observed.

\subsection{TMZ Induces Upregulation of Anti-Apoptotic Factors}

Important players involved in the protection against apoptosis are factors that can block the activation of different executive caspases. Among them, especially members of the Bcl-2 family and the inhibitor of apoptosis (IAP) members have already been associated with SCAPs. To analyze whether one or multiple of these factors act as SCAPs in TMZinduced senescence, we analyzed the expression of these factors in response to TMZ exposure. The data indicate a strong transcriptional activation of $c-I A P 2$ and a weak induction of $c-I A P 1$ and XIAP (Figure 2A).

For $B c l-2$ and $B c l-x L$, no transcriptional alterations were observed, whereas BIRC5/survivin was repressed at early times after exposure. Similar to the data obtained at the transcriptional level, a strong increase in the expression of the c-IAP2 protein was observed 
(Figure 2B). Apart from c-IAP2, an induction of Bcl-2 was also observed at the protein level. For Bcl-xL, c-IAP1, Survivin, and XIAP, only minor alterations were visible.

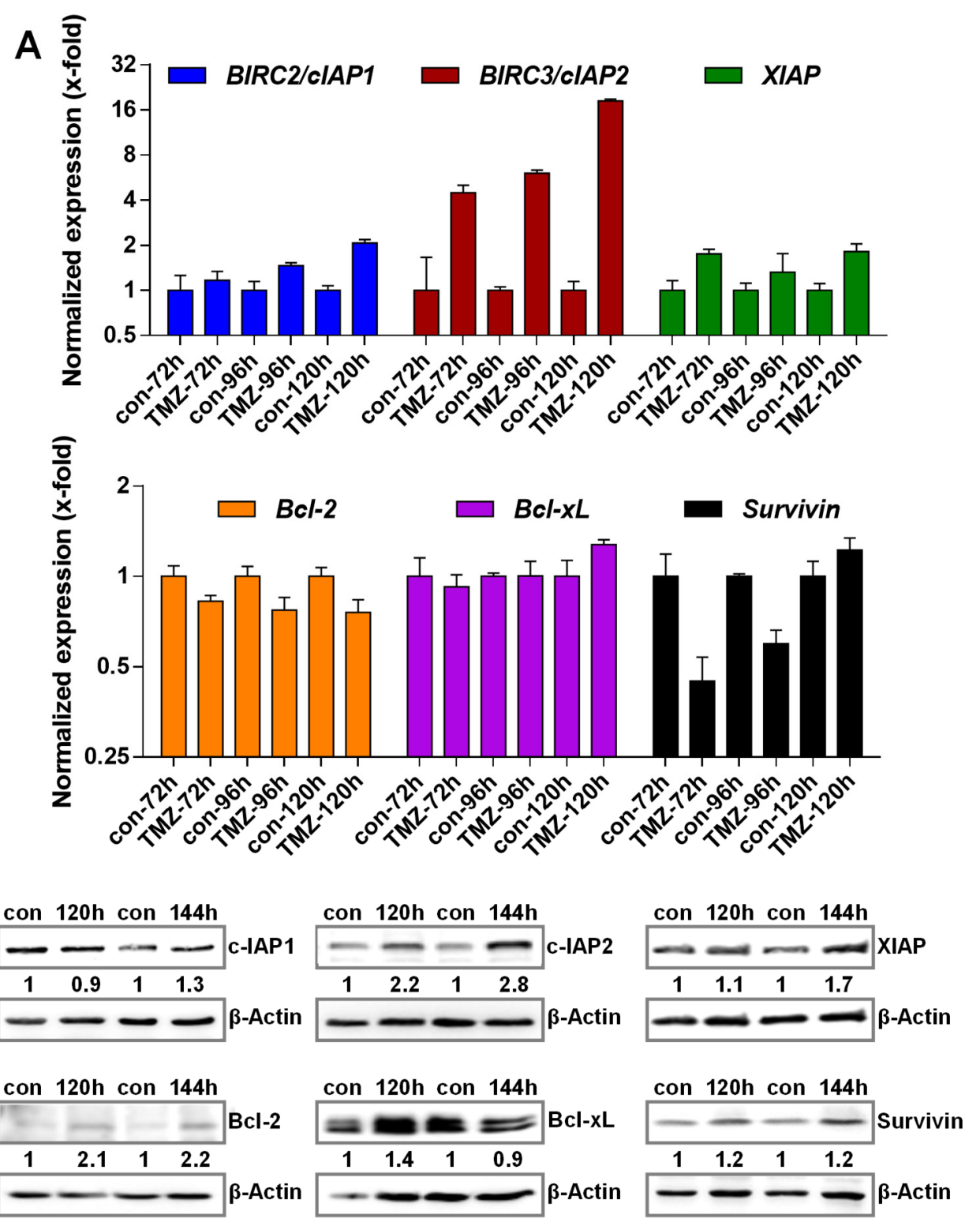

Figure 2. (A) LN-229 cells were treated with $50 \mu \mathrm{M}$ TMZ; 72-120 h later, expression of $c-I A P 1, c-I A P 2$, XIAP, Bcl-2, Bcl- $x L$, and BIRC5/Survivin mRNA was measured by PCR. (B) LN-229 cells were treated with $50 \mu \mathrm{M}$ TMZ; 120 and $144 \mathrm{~h}$ later, expression of Bcl-2, Bcl-xL, c-IAP1, c-IAP2, XIAP, and Survivin protein was measured by immunodetection.

\subsection{Inhibition of Anti-Apoptotic Factors at Early Time Points Impacts TMZ-Induced Cell Death}

To test whether the factors of the IAP and Bcl-2 family might act as SCAPs, we analyzed whether inhibition of these proteins can cause death of senescent LN-229 cells. Therefore, we first identified a non-toxic concentration of the inhibitors embelin (targets XIAP), AT406 (targets c-IAP1 > XIAP), BV6 (targets c-IAP1 and c-IAP2), and venetoclax (targets Bcl-2) in LN-229 cells (Figure A2A). For embelin, toxicity started at $25 \mu \mathrm{M}$, for AT406 at $100 \mu \mathrm{M}$, for BV6 at $10 \mu \mathrm{M}$, and venetoclax was not toxic up to $50 \mu \mathrm{M}$. Next, we analyzed the impact of inhibition of these factors on cell death induction by TMZ. Therefore, cells were exposed to $50 \mu \mathrm{M}$ TMZ for $144 \mathrm{~h}$. The inhibitors were added either simultaneously (sim) or 48, 72, or $120 \mathrm{~h}$ after addition of TMZ to the medium (Figure A2B). Particularly, simultaneous treatment with TMZ and BV6 significantly increased toxicity. This effect 
gradually decreased by adding the inhibitor at later time points. In contrast, venetoclax, embelin, and AT406 treatment did not significantly affect TMZ-induced cell death. The data indicate that c-IAP2 is an important player in protection against TMZ-induced cell death and thereby supports the formation of the senescent phenotype.

\subsection{Inhibition of Anti-Apoptotic Factors Kills Senescent LN-229 Cells}

An intriguing question is whether the anti-apoptotic factors also play a crucial role in protection against cell death in senescent cells. Therefore, we analyzed whether inhibition of the potential SCAP factors can kill senescent cells. LN-229 cells were exposed to $50 \mu \mathrm{M}$ TMZ and incubated for $120 \mathrm{~h}$ to induce senescence. Thereafter, the medium was replaced with fresh, FBS-containing medium, and the cells were either non-treated, again treated with TMZ, or treated with different concentrations of the inhibitors. In contrast to the second TMZ exposure, which had no impact on toxicity, treatment with low, non-toxic concentrations of the inhibitors BV6 and venetoclax significantly increased cell death (Figure 3, left column).

Thus, treatment with $5 \mu \mathrm{M}$ BV6 increased the cell death frequency from 30 to $75 \%$ and treatment with venetoclax from 26 to $>60 \%$. Opposite to BV6 and venetoclax, AT406 and embelin did not affect toxicity (Figure 3, left column). Similar results were observed analyzing cell death using AnnexinV/PI staining. Additionally, in this case, only BV6 and venetoclax dose-dependently enhanced cell death (Figure 3, middle column). Of note, BV6 predominantly increased necrosis/late apoptosis, whereas venetoclax exclusively increased the early-apoptotic cell fraction. To analyze whether higher concentrations of AT406 and embelin impact TMZ-induced toxicity, we repeated the experiments using embelin at a concentration of up to $50 \mu \mathrm{M}$. Interestingly, 10 and $25 \mu \mathrm{M}$ embelin reduced TMZ-induced cell death, whereas $50 \mu \mathrm{M}$ embelin enhanced the toxicity to $>80 \%$ (Figure 3, right column); however, this embelin concentration was already highly toxic on its own (Figure A2A), indicating a non-specific effect. Similar to embelin, high concentrations of AT406 also clearly enhanced cell killing. Of note, the effect was similar in the concentration range 10-100 $\mathrm{MM}$ (Figure 3, right column), and AT406 showed moderate toxicity within this concentration range on its own (Figure A2A). Higher concentrations of venetoclax or BV6 dose-dependently enhanced cell death (Figure 3, right column); however, in the case of BV6, these high concentrations were toxic on their own, whereas for venetoclax, only the highest concentration $(25 \mu \mathrm{M})$ was already toxic on its own (Figure A2A). Overall, the data indicate that non-toxic concentrations of BV6 and venetoclax and to a lesser extent of AT406 but not of embelin increased cell death in the TMZ-treated surviving (senescent) fraction and therefore could be used to eradicate senescent LN-229 cells upon TMZ treatment.
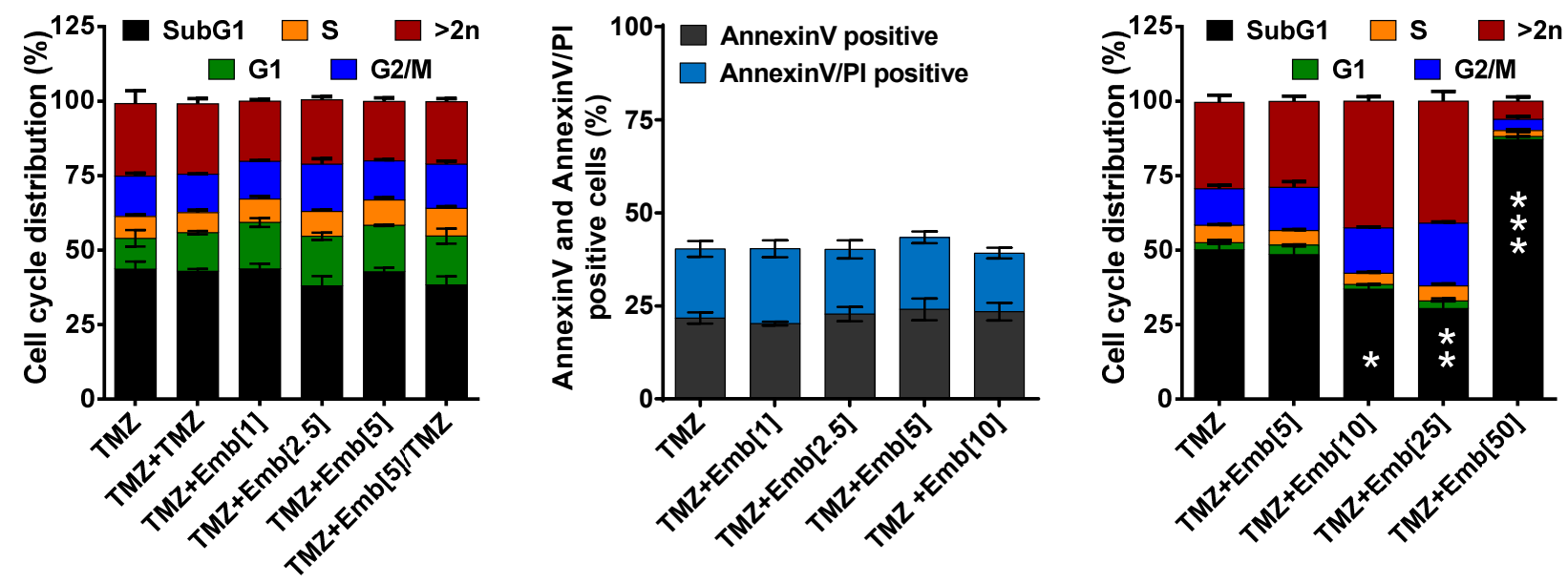

Figure 3. Cont. 

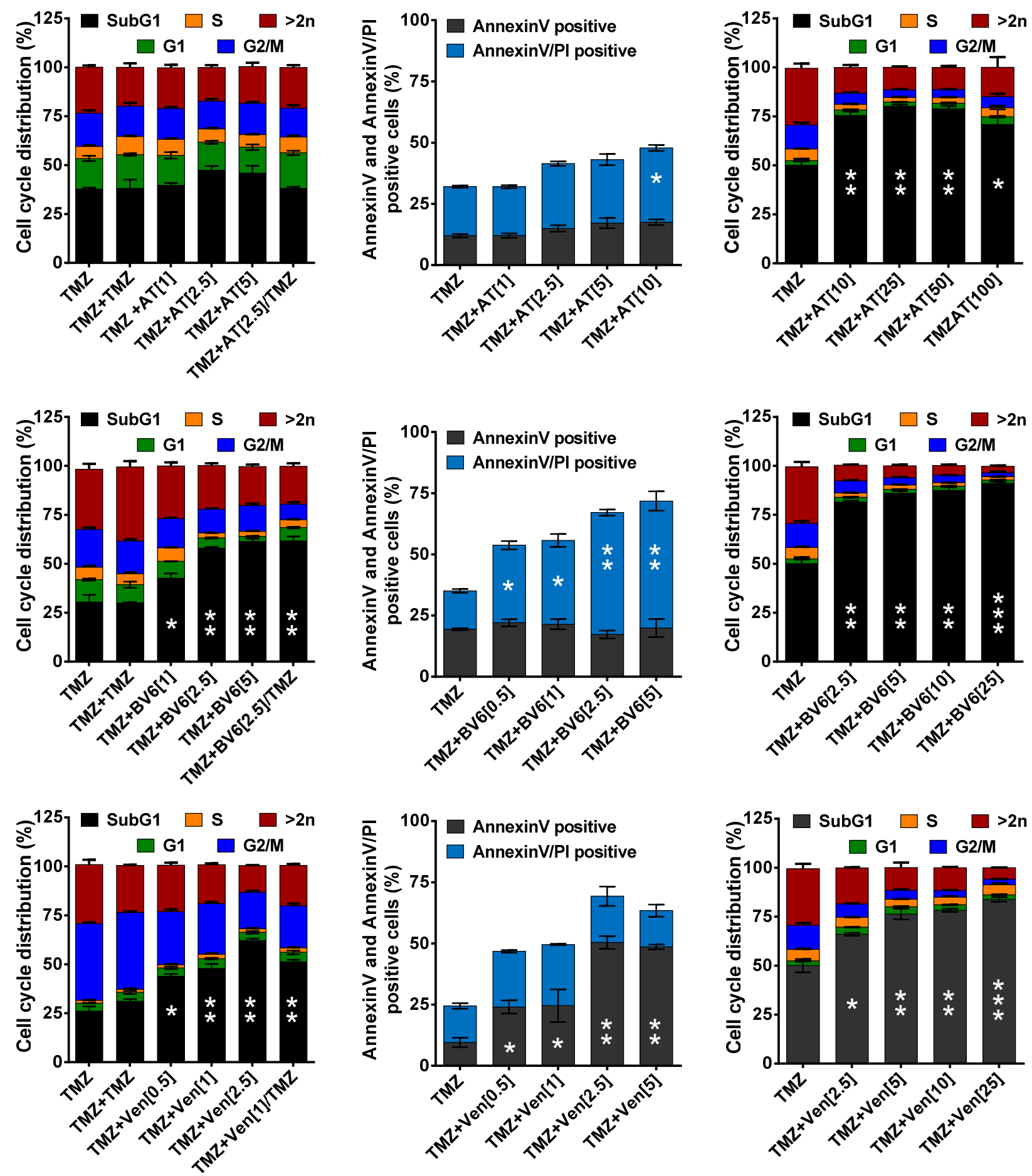

Figure 3. LN-229 cells were treated with $50 \mu \mathrm{M}$ TMZ for $120 \mathrm{~h}$. Thereafter the medium was changed, and the cells were cultivated for additional $120 \mathrm{~h}$, either in the absence (TMZ), the presence of TMZ (TMZ + TMZ), the presence of different concentrations of the inhibitors only (TMZ+embelin, TMZ+AT406, TMZ+BV6, TMZ+venetoclax) or in the presence of the inhibitors combined with TMZ (TMZ+inhibitor/TMZ). Left panel: After $240 \mathrm{~h}$ in total, cell death and cell cycle distribution were measured by flow cytometry using PI staining in LN-229 cells. Middle panel: After total of $240 \mathrm{~h}$, cell death was measured by flow cytometry using AnnexinV/PI staining in LN-229 cells. Right panel: After $240 \mathrm{~h}$, cell death and cell cycle distribution were measured by flow cytometry using PI staining in LN-229 cells. In all cases, experiments were repeated at least three times; mean values \pm SD are shown. Differences in the SubG1 fraction between inhibitor/TMZ treatment and TMZ alone were statistically analyzed using Student's $t$-test (not labeled $=$ not significant, ${ }^{*} p<0.1,{ }^{* *} p<0.01,{ }^{* * *} p<0.001$ ). 
Since the inhibitors target different anti-apoptotic factors, the question arose whether a combination of these inhibitors could further enhance cell death. Therefore LN-229 cells were exposed to $50 \mu \mathrm{M} \mathrm{TMZ}$ for $120 \mathrm{~h}$ to induce senescence. Thereafter, the medium was replaced with fresh, FBS-containing medium, and the cells were either non-treated or treated with the inhibitors alone or in combination. The data show that only the combination of BV6 and venetoclax was effective, enhancing the frequency of cell death from 35\% (TMZ alone), 65\% (BV6 + TMZ), and 60\% (venetoclax + TMZ) to > 80\% (BV6 + venetoclax + TMZ) (Figure $4 \mathrm{~A})$.

All other combinations showed only a minor effect. To substantiate this finding, we used additional BV6 and venetoclax concentrations to identify optimal conditions. Even the combination comprising the lowest concentrations $(1 \mu \mathrm{M}$ BV6/1 $\mu \mathrm{M}$ venetoclax $)$ was sufficient to enhance the toxicity from $35 \%$ to $50 \%$ (Figure $4 \mathrm{~B}$ ). The strongest effect was achieved using the highest BV6 concentration $(5 \mu \mathrm{M})$, culminating in cell death up to $80 \%$. This was independent of the concentration of venetoclax used in the combination, showing the dominant effect of BV6. Only at low BV6 concentrations the toxicity was further enhanced by venetoclax (Figure 4B). Of note, even the highest combination ( $5 \mu \mathrm{M}$ BV6/5 $\mu \mathrm{M}$ venetoclax) showed no significantly enhanced toxicity on its own. The statistical evaluation using Combenefit software confirmed this notion, showing a significant synergy between BV6 and venetoclax in triggering death of senescent LN-229 cells (Figure 4C).

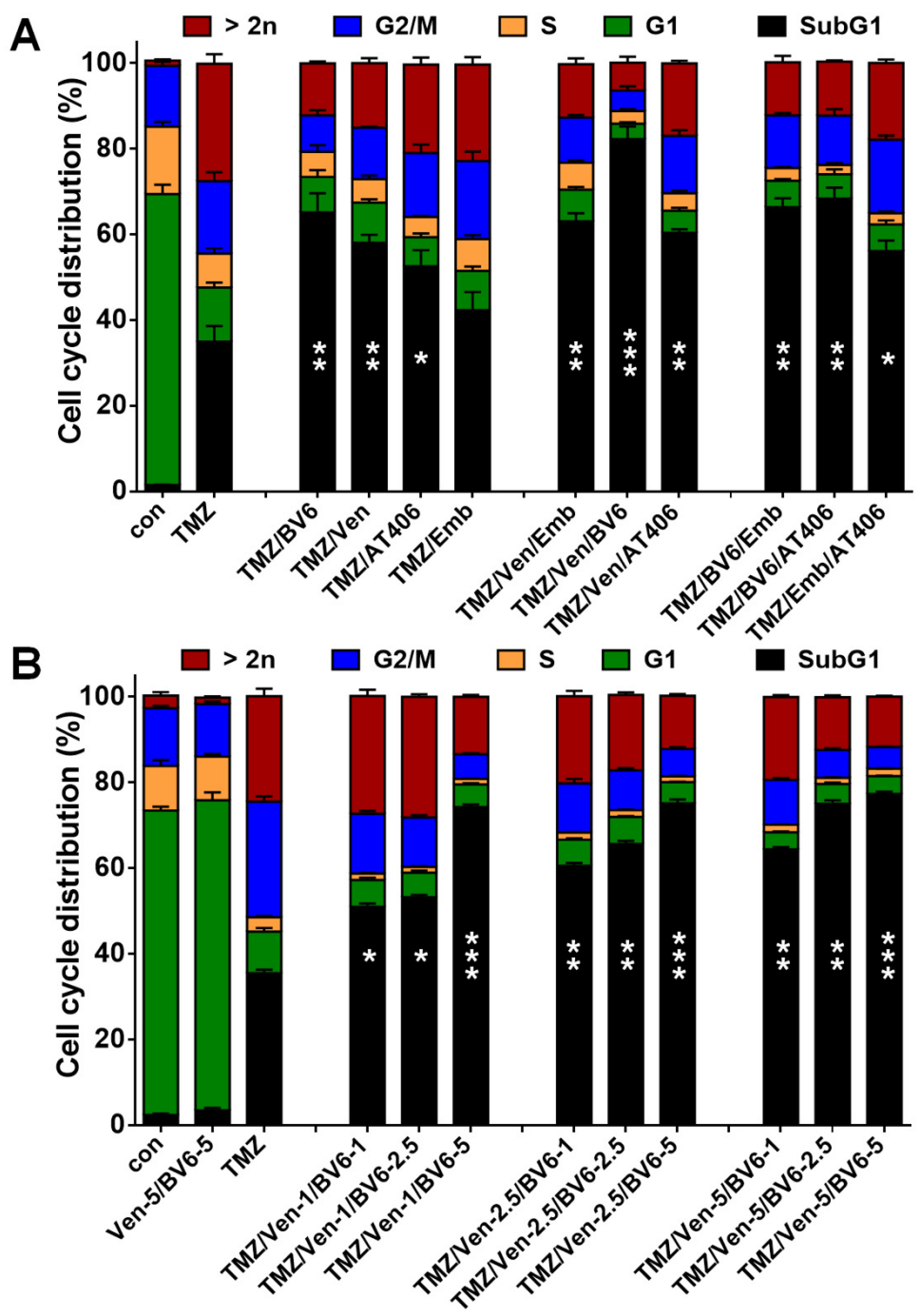

Figure 4. Cont. 

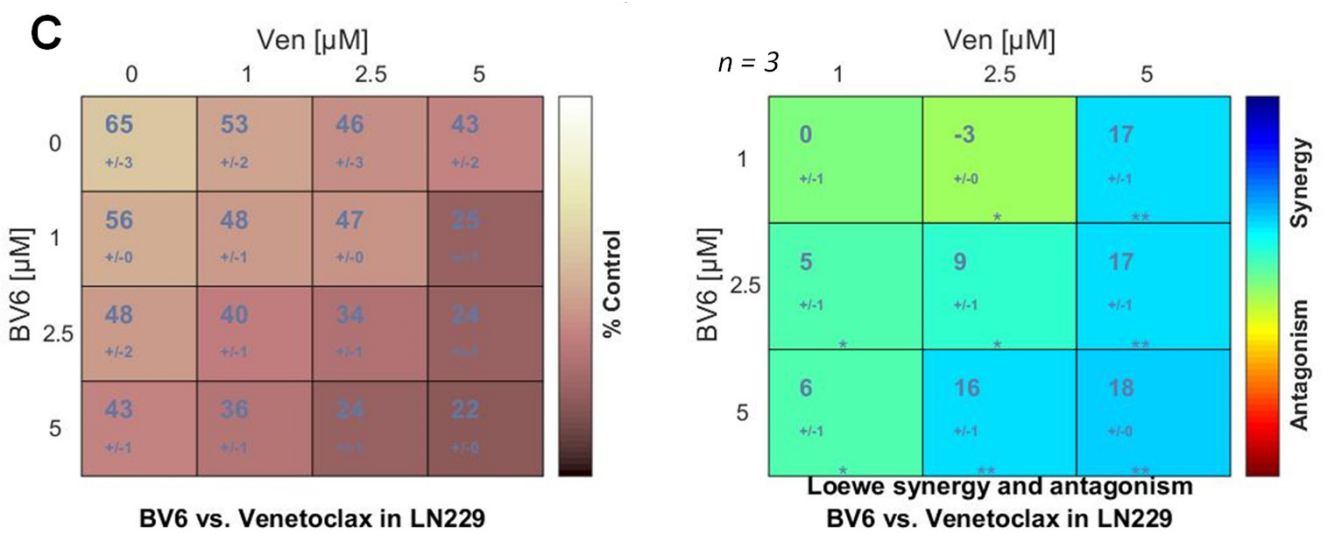

Figure 4. (A) LN-229 cells were treated with $50 \mu \mathrm{M}$ TMZ for $120 \mathrm{~h}$. Thereafter, the medium was changed, and the cells were either further cultivated for an additional $120 \mathrm{~h}$ in the absence (TMZ) or the presence of different concentrations of the inhibitors $(5 \mu \mathrm{M}$ embelin, $5 \mu \mathrm{M}$ AT406, $2.5 \mu \mathrm{M}$ BV6, $2.5 \mu \mathrm{M}$ venetoclax) or in the presence of a combination of two inhibitors. As the control, LN-229 cells were cultivated for $120 \mathrm{~h}$; thereafter, the medium was replaced, and the cells were further cultivated for $120 \mathrm{~h}$ (con). After a total of $240 \mathrm{~h}$, cell death and cell cycle distribution were measured by flow cytometry using PI staining in LN-229 cells. (B) LN-229 cells were treated with $50 \mu \mathrm{M}$ TMZ for $120 \mathrm{~h}$. Thereafter the medium was changed, and the cells were either further cultivated for an additional $120 \mathrm{~h}$ in the absence (TMZ) or the presence of $1,2.5$, or $5 \mu \mathrm{M}$ BV6 combined with $1,2.5$, or $5 \mu \mathrm{M}$ venetoclax. As controls, cells were cultivated for $120 \mathrm{~h}$; thereafter, the medium was replaced, and the cells were further cultivated for $120 \mathrm{~h}$ in the absence (con) or presence of the inhibitors $(5 \mu \mathrm{M}$ BV6/5 $\mu \mathrm{M}$ venetoclax). After a total of $240 \mathrm{~h}$, cell death and cell cycle distribution were measured by flow cytometry using PI staining. (A,B) Experiments were repeated at least three times; mean values \pm SD are shown. Differences in the SubG1 fraction between inhibitor/TMZ treatment and TMZ alone were statistically analyzed using Student's $t$-test (not labeled $=$ not significant, ${ }^{*} p<0.1$, ${ }^{* *} p<0.01,{ }^{* * *} p<0.001$ ). (C) Combenefit software was used to perform surface analyses to identify synergy between BV6 and venetoclax based on the data presented under (B).

As shown previously, senescent tumor cells repress important repair pathways [8]. Therefore, it is anticipated that these cells accumulate DNA damage during senescence and may represent an important trigger for the formation of recurrences upon escape from senescence [35]. To test whether senescence-escaping or senescence-evading cells can be targeted by BV6, we established four cell clones that still proliferate after TMZ exposure. Of note, the frequency at which these clones were built was $\sim 0.02 \%$. Interestingly, all of the clones maintained an increased expression of c-IAP2 and p21 (Figure A3A), while only one clone was still responsive to TMZ (Figure A3B). A significant enhancement of cell death was observed upon BV6 treatment in two of these clones (Figure A3C), indicating that some of the clones that survived the TMZ treatment still require c-IAP2 for survival.

\subsection{Inhibition of Anti-Apoptotic Factors Kills Senescent A172 and U87MG Cells}

Our data obtained in LN-229 cells suggests that particularly c-IAP2 and Bcl-2 act as SCAP factors in TMZ-induced senescence, and that inhibition of these factors could strongly kill these senescent cells. To test this hypothesis, we used two additional MGMTdeficient and p53-proficient glioblastoma cell lines (A172 and U87MG). In these cell lines, TMZ also induced predominantly senescence and not cell death. Thus, $120 \mathrm{~h}$ after exposure to $50 \mu \mathrm{M}$ TMZ, cell death was $<10 \%$ in A172 (Figure 5A) and $<20 \%$ in U87MG cells (Figure 6A). 

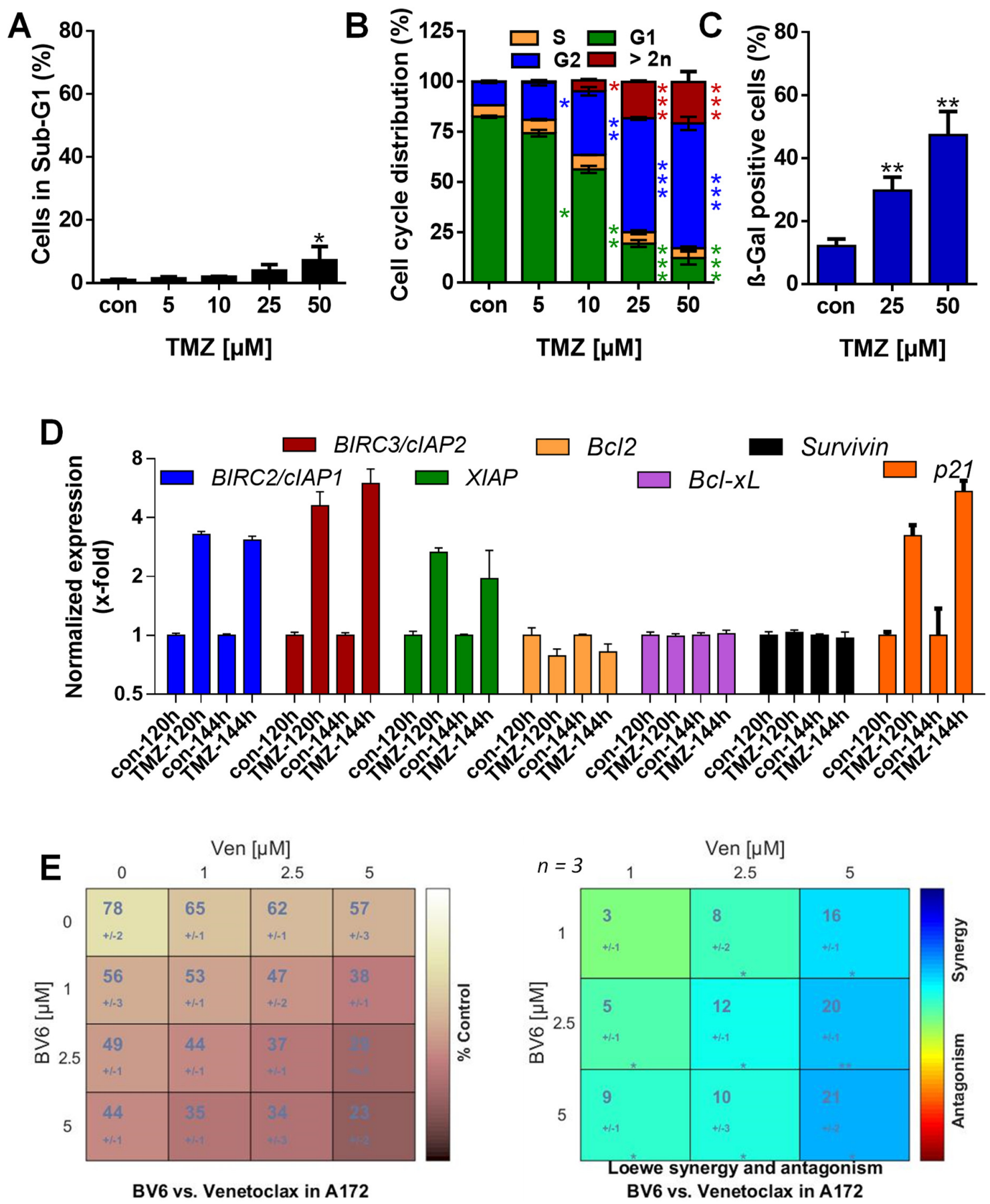

Figure 5. (A) Cell death was measured $120 \mathrm{~h}$ upon exposure to different concentrations of TMZ by flow cytometry using PI staining in A172 cells. (B) Cell cycle distribution was measured $120 \mathrm{~h}$ after exposure to different concentrations of TMZ by flow cytometry using PI staining in A172 cells. (C) Senescence was measured microscopically by detection of $\beta$-Gal positive cells $120 \mathrm{~h}$ after exposure to 25 and $50 \mu \mathrm{M}$ TMZ. (D) A172 cells were treated with $50 \mu \mathrm{M}$ TMZ. Then, 120 and $140 \mathrm{~h}$ later, expression of $c-I A P 1, c-I A P 2, X I A P, B c l-2, B c l-x L$, and BIRC5/Survivin mRNA was measured by PCR. (E) A172 cells were treated with $50 \mu \mathrm{M}$ TMZ for $120 \mathrm{~h}$. Thereafter, the medium was changed, and the cells were either further cultivated for an additional $120 \mathrm{~h}$ in the absence or presence of $1,2.5$, or $5 \mu \mathrm{M}$ BV6 combined with $1,2.5$, or $5 \mu \mathrm{M}$ venetoclax. After a total of $240 \mathrm{~h}$, cell death distribution was measured by flow cytometry using PI staining in A172 cells, and Combenefit software was used to perform surface analyses to identify synergy. (A-C) Experiments were performed in triplicate, and differences between treatment and control were statistically analyzed using Student's $t$-test (not labeled $=$ not significant, ${ }^{*} p<0.1$, $\left.{ }^{* *} p<0.01,{ }^{* * *} p<0.001\right)$. 

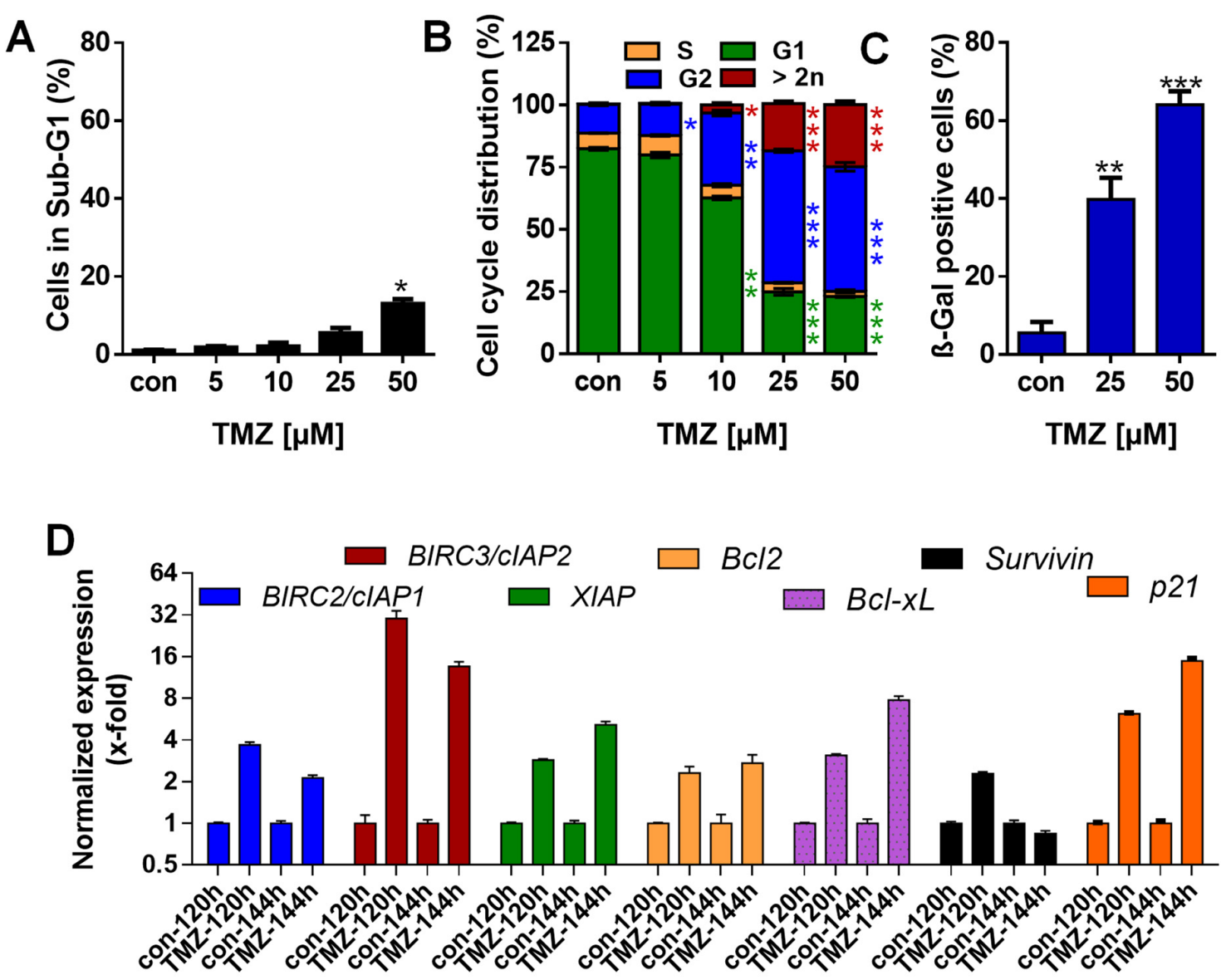

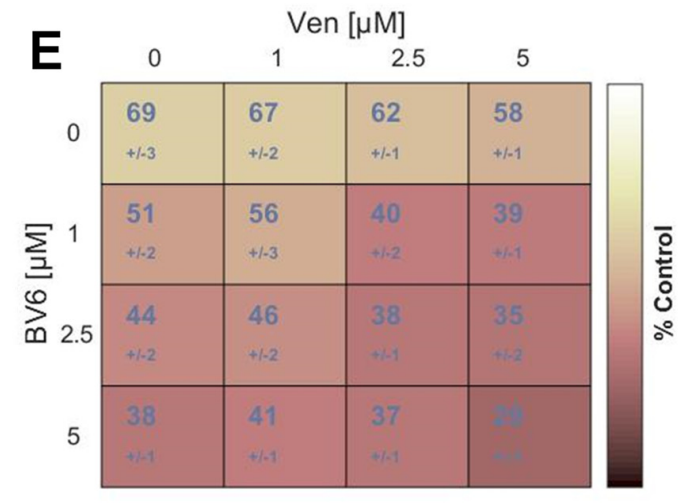

BV6 vs. Venetoclax in U87

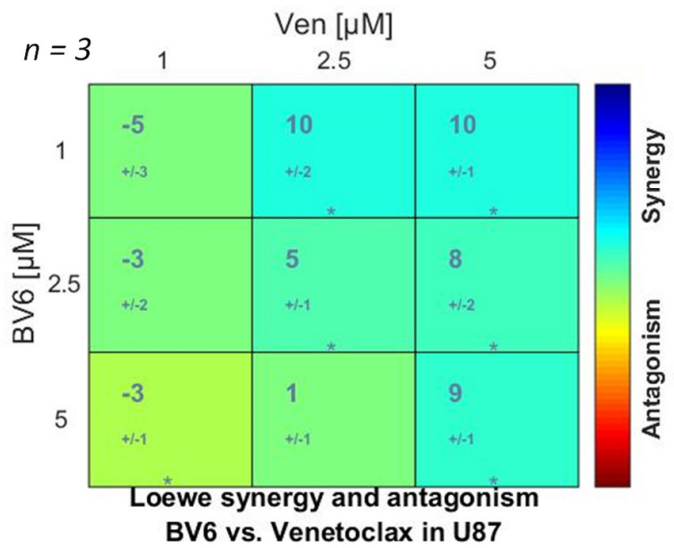

Figure 6. (A) Cell death was measured $120 \mathrm{~h}$ upon exposure to different concentrations of TMZ by flow cytometry using PI staining in U87MG cells. (B) Cell cycle distribution was measured $120 \mathrm{~h}$ upon exposure to different concentrations of TMZ by flow cytometry using PI staining in U87MG cells. (C) Senescence was measured microscopically by detection of $\beta$-Gal positive cells (left panel) or by flow cytometry using $\mathrm{C}_{12} \mathrm{FDG}$ staining (right panel) $120 \mathrm{~h}$ after exposure to 25 and $50 \mu \mathrm{M}$ TMZ. (D) U87MG cells were treated with $50 \mu \mathrm{M}$ TMZ. Then, 120 and $140 \mathrm{~h}$ later, expression of c-IAP1, c-IAP2, XIAP, $B c l-2, B c l-x L$, and BIRC5/Survivin mRNA was measured by PCR. (E) U87MG cells were treated with $50 \mu \mathrm{M}$ TMZ for $120 \mathrm{~h}$. Thereafter, the medium was changed, and the cells were either further cultivated for an additional $120 \mathrm{~h}$ in the absence or presence of 1, 2.5, or $5 \mu \mathrm{M}$ BV6 combined with 1,2.5, or $5 \mu \mathrm{M}$ venetoclax. After a total of $240 \mathrm{~h}$, cell death was measured by flow cytometry using PI staining in U87MG cells, and Combenefit software was used to perform surface analyses to identify synergy. (A-C) Experiments were performed in triplicate, and differences between treatment and control were statistically analyzed using Student's $t$-test (not labeled $=$ not significant, ${ }^{*} p<0.1,{ }^{* *} p<0.01,{ }^{* * *} p<0.001$ ). 
Opposite to cell death, the arrest of the cells in the G2-phase and the appearance of cells with a DNA content $>2 \mathrm{n}$ was significantly enhanced $120 \mathrm{~h}$ after TMZ exposure in both cell lines (Figures $5 \mathrm{~B}$ and $6 \mathrm{~B}$ ). The senescence frequency was $~ 45 \%$ in A172 and $\sim 65 \%$ in U87MG cells (Figures 5C and 6C). Moreover, clonogenic survival dropped to $<20 \%$ at concentrations $\geq 5 \mu \mathrm{M}$ and was completely abolished at $50 \mu \mathrm{M}$ TMZ (Figure A4A). We should note that A172 cells are slower-proliferating in comparison to LN-229 cells. Therefore, we also measured cell death and senescence $144 \mathrm{~h}$ after TMZ treatment; we observed no toxicity, but increased induction of senescence up to $75 \%$ (Figure A4B-D). Similar to LN-229 cells, transcriptional activation of c-IAP1, c-IAP2, and XIAP was observed in A172 and U87MG cells (Figures 5D and 6D). Moreover, U87MG cells exhibited transcriptional activation of $B c l-2$ and $B c l-x L$ (Figure $6 \mathrm{D}$ ). Importantly, also the protein levels of Bcl-2 and c-IAP2 were enhanced in both cell lines after TMZ exposure (Figure A4E).

To analyze whether BV6 and venetoclax also enhance the killing effect in A172 and U87MG cells, the cells were exposed to $50 \mu \mathrm{M}$ TMZ for $120 \mathrm{~h}$ to induce senescence. Thereafter, the medium was replaced with fresh, FBS-containing medium, and the cells were left either untreated or were treated with the inhibitors, either single or combined. The data show that, similar to LN-229 cells, a clear dose-dependent increase of toxicity was observed for all combinations of BV6 and venetoclax. In detail, cell death frequency was enhanced in A172 cells from $27 \%$ to $~ 50 \%$ at the lowest concentrations $(1 \mu \mathrm{M} \mathrm{BV} 6 / 1 \mu \mathrm{M}$ venetoclax) and to $\sim 80 \%$ at the highest concentrations ( $5 \mu \mathrm{M} \mathrm{BV} 6 / 5 \mu \mathrm{M}$ venetoclax) (Figure A5), and in U87MG cells cytotoxicity was increased from $29 \%$ to $~ 60 \%$ at the lowest concentrations $(1 \mu \mathrm{M} \mathrm{BV} 6 / 1 \mu \mathrm{M}$ venetoclax) and to $\sim 80 \%$ at the highest concentrations $(5 \mu \mathrm{M} \mathrm{BV} 6 / 5 \mu \mathrm{M}$ venetoclax) (Figure A6). In addition, for U87MG and A172 cells, the statistical evaluation using Combenefit analysis showed a significant synergy between BV6 and venetoclax in the killing of senescent cells (Figures 5E and 6E). Similar to LN229, the combination of $5 \mu \mathrm{M}$ BV6 and $5 \mu \mathrm{M}$ venetoclax was not toxic by itself in U87MG and A172 cells. Of note, also in telomerase immortalized human epithelial cells (RPE-1 and HCEC-1CT), as well as in telomerase immortalized human astrocytes, this treatment was not toxic, either in the absence or presence of TMZ (Figure A7).

Overall, the presented data clearly supports our hypothesis that c-IAP2 and Bcl-2 act as SCAP factors in TMZ-induced senescence, and that inhibition of these factors could be used to enhance TMZ-triggered cell death of glioma cells.

\section{Discussion}

Therapy of high-grade gliomas rests on treatment with the methylating anticancer drug TMZ. However, at treatment-relevant doses, only a minor fraction of tumor cells is killed by apoptosis; malignant glioma cells rather undergo senescence $[7,8]$. This is likely the reason why TMZ treatment can only extend the median survival of patients from 12.1 up to 14.6 months [2]. Induction of apoptosis and senescence by TMZ is triggered via induction of the minor DNA lesion $O^{6} \mathrm{MeG}$ and subsequent activation of the DDR [45]. Using synchronized cells, it was shown that $O^{6} \mathrm{MeG}$ triggers accumulation of cells in the G2/M-phase of the post-treatment cell cycle [46]. Moreover, we could show that TMZinduced senescence is associated with a strong NF- $\mathrm{kB}$ dependent induction of the SASP phenotype [8]. Since senescent cells may represent a threat for a patient during therapy caused by the SASP or by potential senescence evasion and associated increase in aggressiveness, targeting senescent cells during or after TMZ treatment could be therapeutically beneficial [35].

Since elimination of senescent cells by senolytic drugs may be cell-type specific [47], we performed our study in three different glioblastoma cell lines. Treatment of LN-229, A172, and U87MG cells with $50 \mu \mathrm{M}$ TMZ for $120 \mathrm{~h}$ induced cell death only up to $20 \%$. At the same time, up to 70,45 , or $65 \%$ of senescent cells, respectively, were induced by the drug. Of note, also for A172, the amount of senescent cells increased up to $75 \%$ at later post-exposure times. In all cell lines, senescence was accompanied by arrest in the G2-phase of the cell cycle, which confirms previous reports [8,48]. All cell lines showed the 
emergence of polyploid cells (20-30\% of the population) upon treatment with $50 \mu \mathrm{M} \mathrm{TMZ}$ and a post-exposure time of $120 \mathrm{~h}$. Very recently, we reported that glioma cells showing a strong accumulation of nuclear Survivin also exhibit an increased polyploid cell population after exposure to TMZ [48]. This indicates that a high frequency of cells was able to undergo incomplete cell division. Since most of the cells are tetraploid ( $4 \mathrm{n})$, the data indicate that these cells have completed mitosis but failed to undergo cytokinesis, most likely due to chromosome mis-segregation. It has been shown that abnormal mitosis triggers p53dependent cell cycle arrest in human tetraploid cells [49]. Therefore, we suppose that tetraploidy is also involved in triggering and maintaining TMZ-induced senescence. It has also been shown that during senescence, polyploidization is associated with re-replication of damaged G2/M cells, which could be associated with senescence-specific occurrence of heterochromatinization [50]. Of note, these tetraploid cells were also found among senescence-escaping cells. On the other hand, during carcinogenesis, senescence can block cell transformation of normal cells due to a specific G1-checkpoint in tetraploid cells [51].

The idea of using agents that specifically kill senescent cells, i.e., senolytic drugs [52], is based on the observation that senescent human fibroblasts resist apoptosis [53]. In this early study, the involvement of anti-apoptotic pathways was established, suggesting that Bcl-2 is important for apoptosis evasion of senescent cells. This led to the positing of a "Senescent Cell Anti-Apoptotic Pathway (SCAP)", which is important for blocking apoptosis and thereby triggering senescence [54]. Based on the dominant role of anti-apoptotic factors in the SCAP, we analyzed which factors are involved in apoptosis evasion in TMZ-induced senescence of glioblastoma cells. Thus, we analyzed expression of the anti-apoptotic factors Bcl-2, Bcl-xL, c-IAP1, c-IAP2, XIAP, and Survivin and elucidated whether inhibition of these factors could enhance cell killing by targeting senescent cells.

Here we show that TMZ induced a strong transcriptional activation of $c-I A P 2$ and a weak induction of $c-I A P 1$ and XIAP in LN229, A172, and U87MG cells. In U87MG cells, $B c l-2$ and $B c l-x L$ were also transcriptionally activated. The induction of c-IAP2 was also observed at the protein level. Furthermore, Bcl-2 also showed increased protein expression, which seems to be regulated by post-transcriptional mechanisms. Overall, the data show a strong activation of anti-apoptotic factors. Therefore, we analyzed whether inhibition of these factors enhances TMZ-induced cell death at early time points (senescence induction) and at later times (senescence maintenance). The data reveal that BV6, predominantly targeting c-IAP1/c-IAP2 and to a lesser extent XIAP (but not venetoclax, targeting Bcl-2/ embelin, targeting XIAP / or AT406, targeting c-IAP1), significantly increased toxicity already at early time points. Similar data were also observed during late stages of senescence. In these experiments, cells were exposed to $50 \mu \mathrm{M} \mathrm{TMZ}$ for $120 \mathrm{~h}$ to induce senescence and after medium replacement exposed to TMZ or to the inhibitors for an additional $120 \mathrm{~h}$. Interestingly, at this time point, e.g., $240 \mathrm{~h}$ after TMZ exposure, the cell death of the TMZ-only treated cells amounted to $25-40 \%$, indicating ongoing induction of cell death also at very late times after TMZ exposure. We should note that additional treatment with TMZ was not able to enhance toxicity. The same was also observed upon exposure to the topoisomerase II inhibitor teniposide and the PARP inhibitor pamiparib (Figure A8). In contrast, treatment with non-toxic concentrations of BV6 and venetoclax, but not with AT406 and embelin, eradicated the senescent cells.

Our data clearly show that SCAP inhibition efficiently kills TMZ-treated cells. However, it is not possible to formally prove that only senescent cells were killed, i.e., that the killing was a purely senolytic effect. Our data reveal that the inhibition of c-IAP1/2 and of Bcl-2 also kills cells at early time points after TMZ exposure. After all, this is to be expected, since the SCAP is a prerequisite for the onset of senescence. Thus, inhibition of the SCAP can also trigger cell death at early time points before development of the senescent phenotype in TMZ-exposed cells. In addition, $120 \mathrm{~h}$ after TMZ exposure, cells not yet displaying a senescent phenotype could therefore be killed. It is however more likely that particularly cells already showing the senescent phenotype are killed. This is supported by the fact that in colony-forming assays, only $0.02 \%$ of LN-229 cells were able 
to proliferate and is also substantiated by the finding that $240 \mathrm{~h}$ after TMZ exposure, nearly $100 \%$ of the surviving cells are senescent (data not shown).

The killing effect of BV6 and venetoclax could even be enhanced by combining these drugs, as indicated by the observed synergistic effect and the statistically evaluated Loewesynergy, calculated via Combenefit. Comparing the efficiency of BV6 and venetoclax in all three cell lines revealed that BV6 is more effective in killing senescent cells. This is also reflected by the low $\mathrm{EC}_{50}$ for BV6 (LN-229: $1.67 \mu \mathrm{M}$; A172: $2.19 \mu \mathrm{M}$; U87MG: $\left.1.1 \mu \mathrm{M}\right)$ (Figure A9). For venetoclax, a low $\mathrm{EC}_{50}$ was only observed in LN-229, but not in A172 $(>5 \mu \mathrm{M})$ and U87MG $(19.4 \mu \mathrm{M})$ cells.

The importance of Bcl-2 as a mediator of SCAP was also reported during doxorubicininduced senescence in breast cancer cells. Here, the Bcl-2/Bcl-xL/Bcl-w inhibitor ABT-263 efficiently killed senescent cells [55]. Moreover, senescent prostate cancer cells, accumulating DNA damage induced by ionizing radiation and PARP inhibition, were killed by the Bcl-2 inhibitors navitoclax and ABT-737 [56]. In contrast, upon TMZ-induced senescence, c-IAP2 seems to play a prevailing role in mediating the SCAP, which was also indicated by the Combenefit analyses. Of note, our data are in line with those showing that BV6 can sensitize glioblastoma cells to TMZ [57] and that BIRC3/c-IAP2 up-regulation results in apoptosis evasion and therapeutic resistance in glioblastoma [58]. Moreover, concerning the impact of IAP inhibition on anticancer drug therapy, we could already show that colorectal cancer (CRC) cells could be sensitized to irinotecan by the Survivin inhibitor LLP3 [59,60] and, most importantly, BV6 also sensitized CRC cells to irinotecan [61].

We should note that an unresolved problem concerning in vitro studies using TMZ is based on the applied concentrations [62]. Whereas the median serum concentration of TMZ achieved is $50 \mu \mathrm{M}$ [63], the data are less clear for the cerebrospinal fluid. Thus, peak concentrations in the cerebrospinal fluid are in the range of 14.95-34.54 $\mu \mathrm{M}$ [64], 0.82-9.94 $\mu \mathrm{M}$ [65], 1.55-4.64 $\mu \mathrm{M}$ [66], and 1.49-4.17 $\mu \mathrm{M}$ [67]. In vitro, among 12 glioma cell lines, only LN-229 had an $\mathrm{EC}_{50}<100 \mu \mathrm{M}$ in the acute cytotoxicity assay [68]. Opposite, concerning clonogenic survival, most cell lines have an $\mathrm{EC}_{50}<100 \mu \mathrm{M}$. This suggests that under clinical conditions, TMZ is not cytotoxic but rather cytostatic [69]. Additionally, in vitro, TMZ predominantly induced senescence and not cell death [8]. In our experiments, only at late time points a significant TMZ-induced toxicity was observed in A172 and U87MG cells. LN-229 showed a higher frequency of cell death at 25 and $50 \mu \mathrm{M}$, whereas concentrations of 5 and $10 \mu \mathrm{M}$ were not toxic but strongly affected clonogenic survival in all cell lines (present publication, [8]). It is important to note that in the low concentration ranges between 1 and $25 \mu \mathrm{M} \mathrm{TMZ}$, a linear increase with dose in the activation of the DNA damage response, cell death, and senescence was observed without a no-effect threshold $[43,44]$. For in vitro experiments, higher concentrations are often necessary, since established cell lines are more robust and not as responsive as cells in vivo. This is already the case for freshly established glioblastoma tumor spheres [70]. Nevertheless, in these tumor spheres, responders and non-responders could be separated in vitro, and a direct relationship was found between sensitivity of tumor spheres to TMZ and patients survival [70]. The increased resistance to TMZ in vitro can be ascribed to multiple adaptive events in cell culture, e.g., differentiation that gradually shifts terminally differentiated cells to a post-mitotic state [71], as well as to epigenetic alterations or even to pro-survival serum factors. In summary, the fact that the concentrations used for in vitro experiments are higher than those observed in vivo should not prevent pre-clinical work to uncover pathways that could be targeted to improve the therapeutic response of patients. In addition, other application schedules, such as Ommaya reservoirs could achieve higher concentrations of the drugs used [72]. Therefore, it would be highly important to include inhibitors of c-IAP2 and Bcl-2 in future studies using orthotopic models and to develop more efficient and blood-brain barrier-penetrating drugs. 


\section{Conclusions}

Overall, our data presented here and previously published indicate that in glioblastoma cells, TMZ induces senescence to a significantly higher level than cell death through apoptosis and necrosis $[7,8,43,48]$. Senescence is associated with activation of several antiapoptotic factors, such as Bcl-2, c-IAP1, and c-IAP2. The Bcl-2-inhibitor venetoclax and the c-IAP1/c-IAP2 inhibitor BV6 can enhance TMZ toxicity at early times after TMZ treatment and, most importantly, also target senescent glioblastoma cells at later times. Our data indicate that Bcl-2 and c-IAP2 represent the core of the SCAP in TMZ-induced senescence and, therefore, point to the need for in vivo studies, targeting these factors to improve TMZ-based glioblastoma therapy.

Supplementary Materials: The following are available online at https:/ /www.mdpi.com/article/10 .3390 / cancers13143585/s1, Figure S1: Uncut immunodetection generated by direct scanning the area of interest using the iBright CL1000 (Invitrogen) system.

Author Contributions: Conceptualization, M.C. and M.T.T.; investigation, B.R., C.S., M.C., L.T., L.B., J.B.V.; writing—original draft preparation, M.C.; writing—review and editing, M.C., M.T.T., B.K., C.S.; supervision, M.C.; funding acquisition, B.K., M.C., M.T.T. All authors have read and agreed to the published version of the manuscript.

Funding: This research was funded by a grant of the Wilhelm Sander Foundation (2019.154.1) to M.T.T. and M.C., by a grant of the German Science Foundation (DFG CH 655/6-1) to M.C., and by a grant of the German Science Foundation (DFG KA724/31-1) to B.K.

Institutional Review Board Statement: Not applicable.

Informed Consent Statement: Not applicable.

Data Availability Statement: Data is contained within the article or Supplementary Material.

Acknowledgments: We thank Giuseppina Ettari for helpful support in the lab.

Conflicts of Interest: The authors declare no conflict of interest.

\section{Appendix A}

Table A1. Primer sequences used for qPCR.

\begin{tabular}{|c|c|}
\hline Gene & Primer Sequence $\left(5^{\prime}-3^{\prime}\right)$ \\
\hline$A C T B-f w$ & TGGCATCCACGAAACTACC \\
\hline ACTB-rev & GTGTTGGCGTACAGGTCTT \\
\hline$B c l 2-f w$ & TTCAGAGACAGCCAGGAGAAA \\
\hline Bcl2-rev & AGTACCTGAACCGGCACCT \\
\hline$B C L x L-f w$ & AAGCGTAGACAAGGAGAT \\
\hline$B C L x L-r e v$ & TAGGTGGTCATTCAGGTAA \\
\hline$B I R C 2 / c-I A P 1-f w$ & TTCCCAGGTCCCTCGTATCA \\
\hline BIRC2/c-IAP1-rev & CCGGCGGGGAAAGTTGAATA \\
\hline$B I R C 3 / c-I A P 2-f w$ & TCACTCCCAGACTCTTTCCA \\
\hline BIRC3/c-IAP2-rev & CCCCGTGTTCTACAAGTGTC \\
\hline BIRC5/survivin-fw & ATGACTTGTGTGTGATGA \\
\hline BIRC5/survivin-rev & GTTTGTGCTATTCTGTGAA \\
\hline CDNK1a-fw & TACATCTTCTGCCTTAGT \\
\hline CDNK1a-rev & TCTTAGGAACCTCTCATT \\
\hline GAPDH-fw & CATGAGAAGTATGACAACAG \\
\hline GAPDH-rev & ATGAGTCCTTCCACGATA \\
\hline$X I A P-f w$ & CCGAAGAGAAACCACATTT \\
\hline XIAP-rev & CTGAGCCAGATCAAAGTATG \\
\hline
\end{tabular}


Table A2. Antibodies used for immunodetection.

\begin{tabular}{ccccc}
\hline Protein & $\begin{array}{c}\text { Molecularweight } \\
\text { (kDa) }\end{array}$ & Antibody & RRID & Company \\
\hline B-Actin & 42 & sc-47778 & AB_2714189 & Santa Cruz Biotechnology \\
C-IAP1 & 70 & $7065 S$ & AB_10890862 & Cell Signaling Technology \\
C-IAP2 & 68 & $3130 S$ & AB_10693298 & Cell Signaling Technology \\
BCL-2 & 26 & 4223 & AB_1903909 & Cell Signaling Technology \\
BCL-xL & 26 & 2764 & AB_2228008 & Cell Signaling Technology \\
Survivin & 16 & $2808 S$ & AB_2063948 & Cell Signaling Technology \\
XIAP & 57 & $14334 S$ & AB_2784533 & Cell Signaling Technology \\
HRP conjugated & & KCB002 & AB_10703407 & Rockland \\
anti-mouse & & KCB003 & AB_10702763 & Rockland \\
HRP conjugated & & & & \\
anti-rabbit & & & &
\end{tabular}
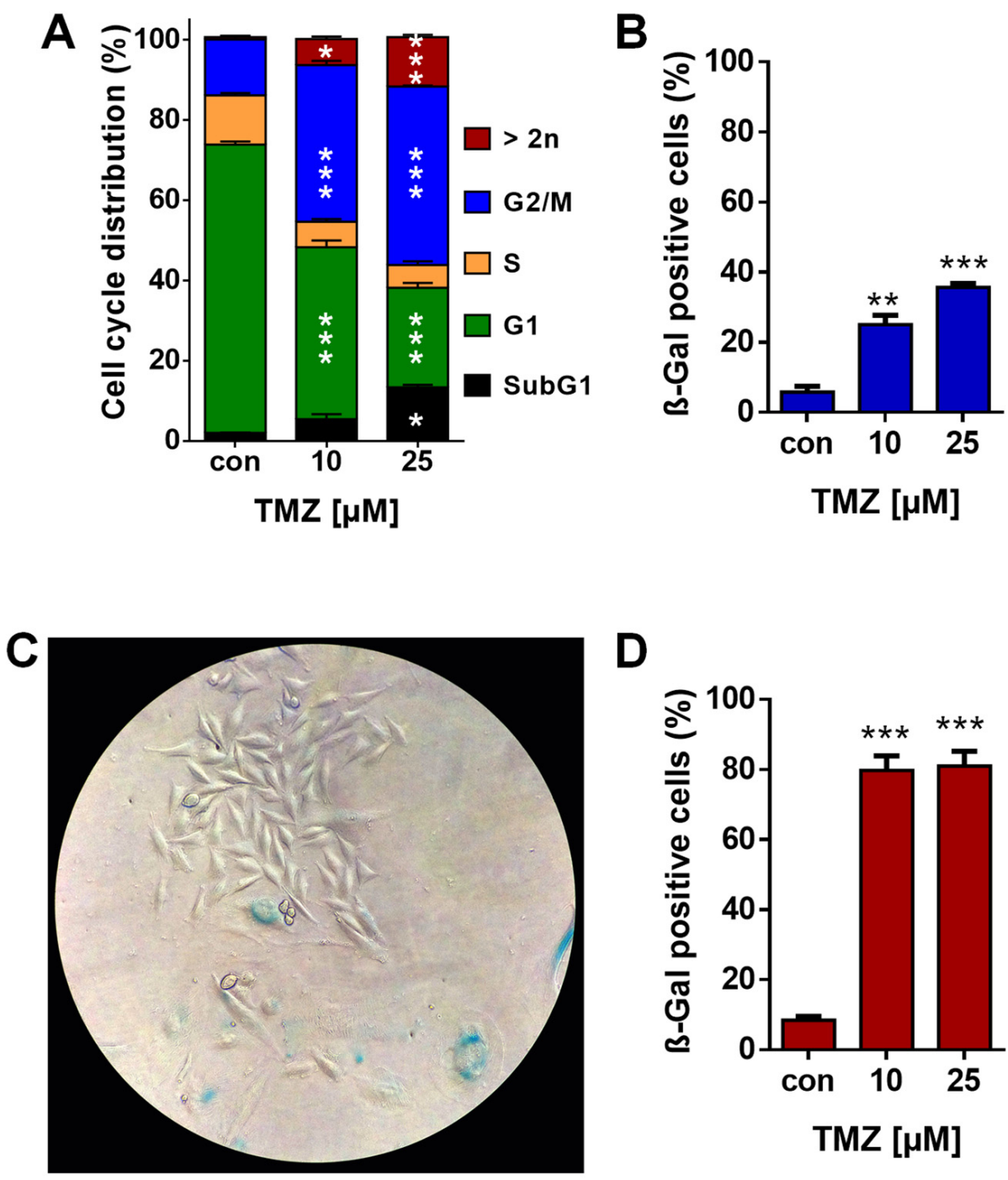

Figure A1. (A) Cell death and cell cycle distribution were measured $144 \mathrm{~h}$ upon exposure to 10 and $25 \mu \mathrm{M}$ TMZ by flow cytometry using PI staining in LN-229 cells. (B) Senescence was measured by B-Gal staining $144 \mathrm{~h}$ after exposure to 10 or $25 \mu \mathrm{M}$ TMZ. (C) Microscopical image showing $\beta$-Gal negative colony-forming cells and separated $\mathrm{B}$-Gal positive cells $144 \mathrm{~h}$ after exposure to $10 \mu \mathrm{M} \mathrm{TMZ}$. (D) Experiments presented under B were re-evaluated, counting colonies as single cells. (A,B,D) Experiments were performed in triplicate, and differences between treatment and control were statistically analyzed using Student's $t$-test (not labeled $=$ not significant, ${ }^{*} p<0.1,{ }^{* *} p<0.01$, *** $p<0.001)$. 

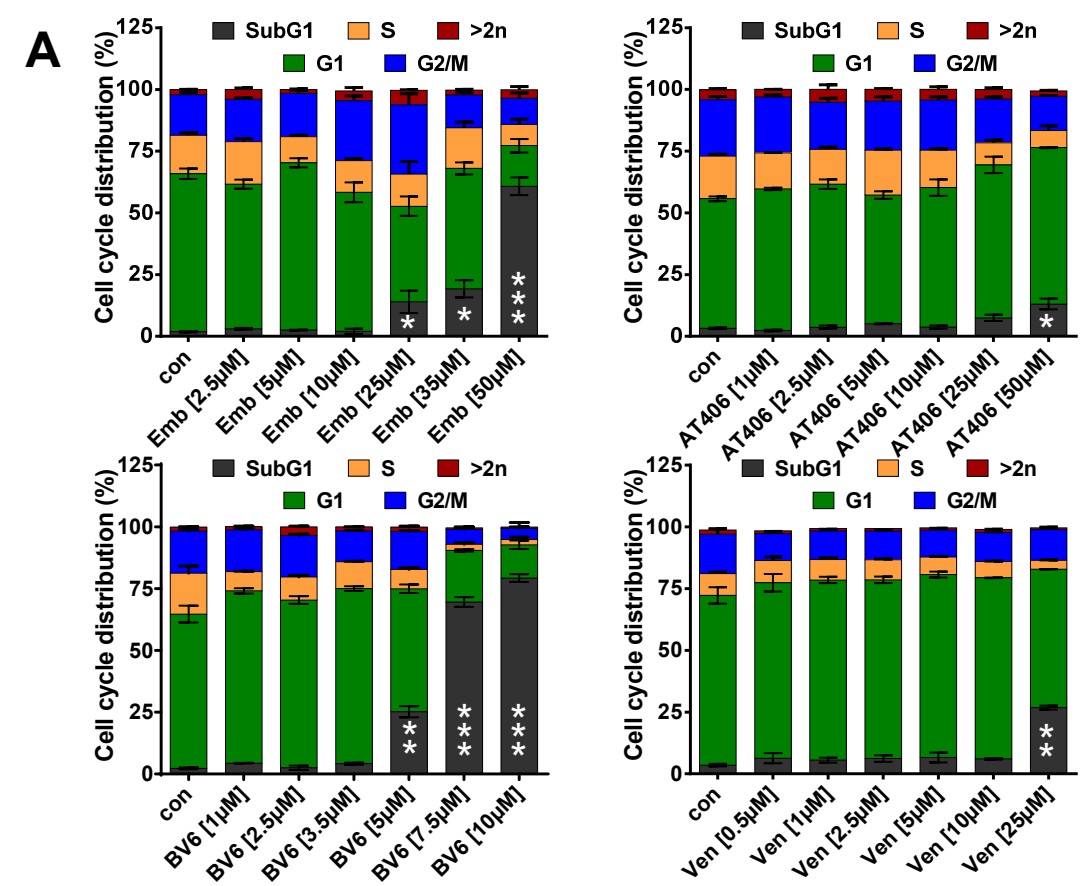

B
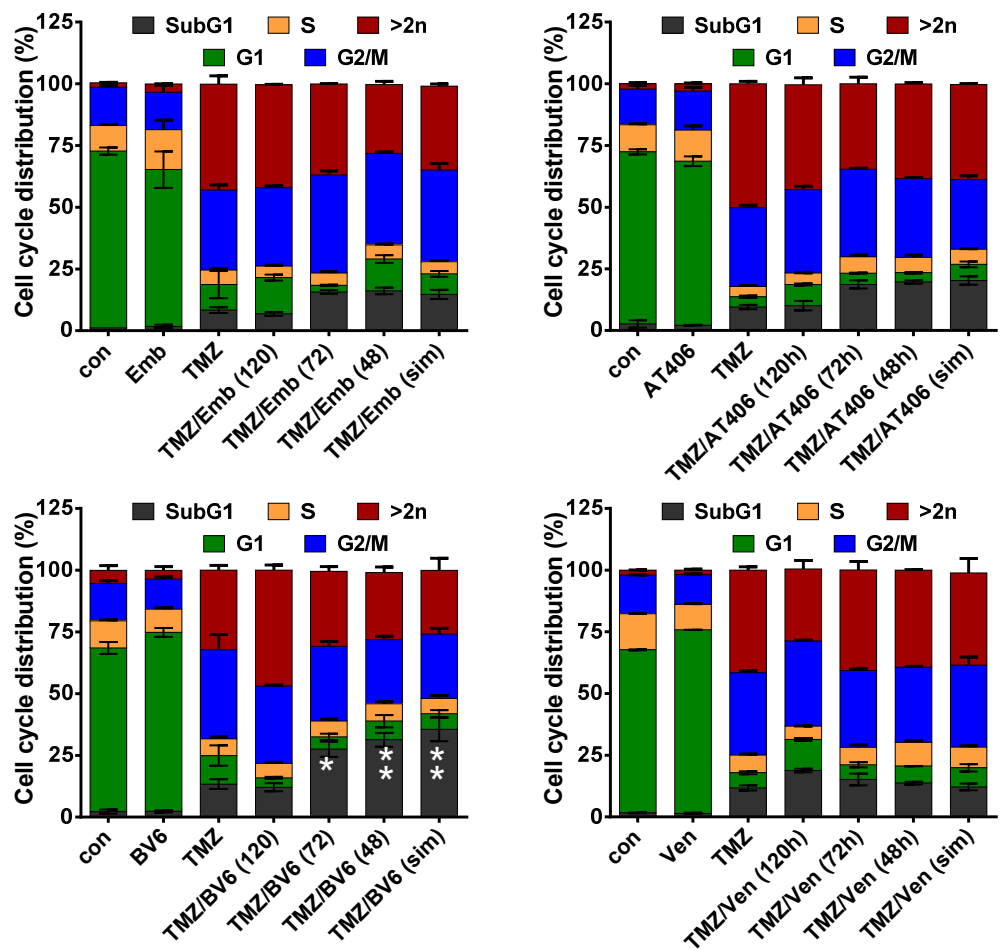

Figure A2. (A) LN-229 cells were treated with different concentrations of the XIAP inhibitor embelin, the c-IAP1 inhibitor AT406, the c-IAP1/c-IAP2 inhibitor BV6, and the Bcl 2 inhibitor venetoclax for $120 \mathrm{~h}$. Cell death and cell cycle distribution were measured by flow cytometry using PI staining in LN-229 cells. (B) LN-229 cells were either non-treated (con) or treated with $50 \mu \mathrm{M}$ TMZ for $120 \mathrm{~h}$ (TMZ). In addition, $5 \mu \mathrm{M}$ embelin, $1 \mu \mathrm{M}$ AT406, $1 \mu \mathrm{M}$ BV6, or $5 \mu \mathrm{M}$ venetoclax were added either simultaneously with TMZ (sim) or 48, 72, or 120 after TMZ exposure. Cell death and cell cycle distribution was measured by flow cytometry using PI staining in LN-229 cells. (A,B) Experiments were repeated at least three times; mean values \pm SD are shown. Differences in the SubG1 fraction between control and TMZ treatment (A) and TMZ and inhibitor/TMZ treatment (B) were statistically analyzed using Student's $t$-test (not labeled $=$ not significant, ${ }^{*} p<0.1,{ }^{* *} p<0.01,{ }^{* * *} p<0.001$ ). 


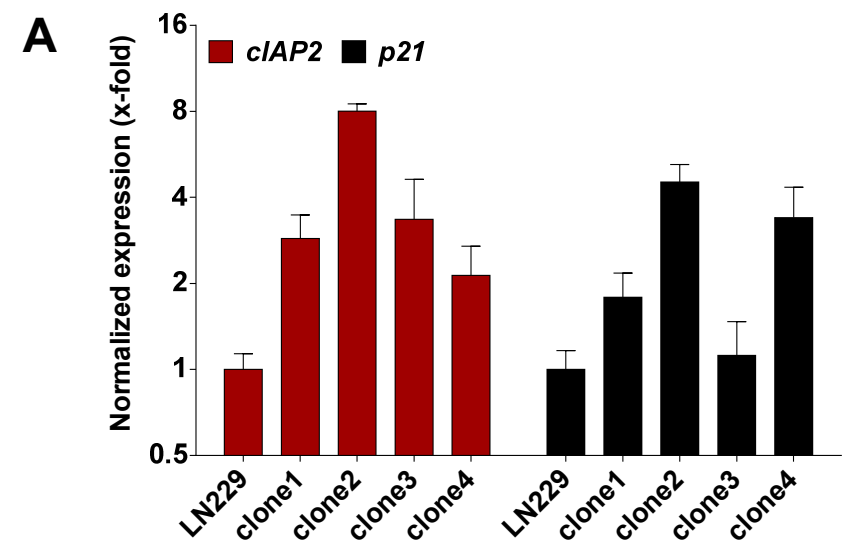

B

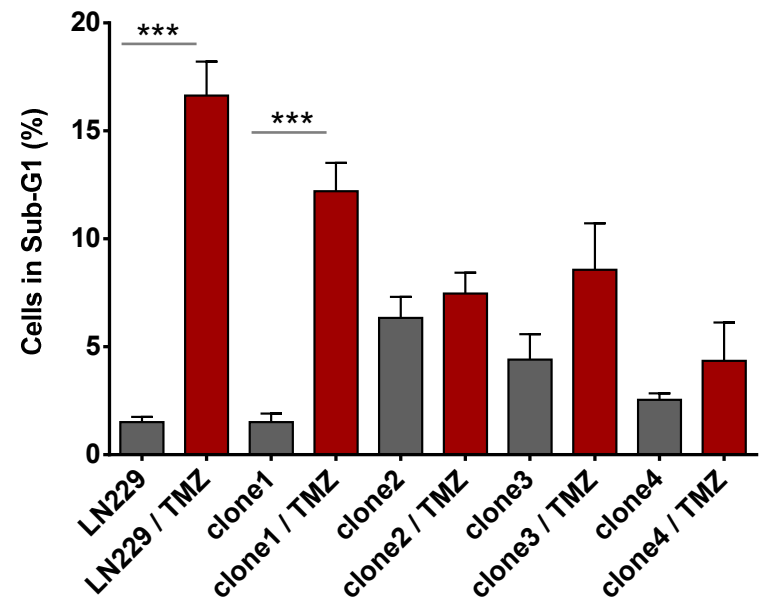

C

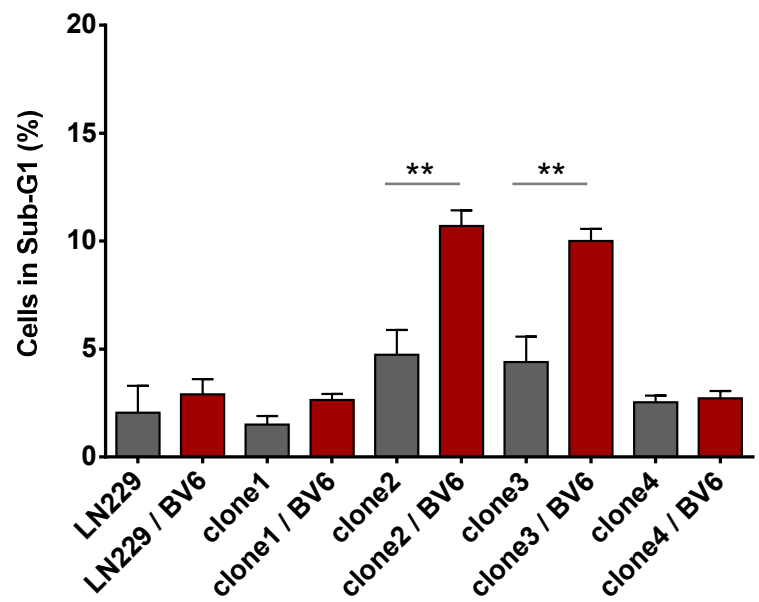

Figure A3. (A) LN-229 cells were treated with $50 \mu \mathrm{M}$ TMZ. Four weeks later, four still proliferating colonies were picked, from which four cell clones were established. Expression of c-IAP2 and p21 mRNA were measured by real-time qPCR. (B) LN-229 cells and the four cell clones were treated with $50 \mu \mathrm{M}$ TMZ. Then, $144 \mathrm{~h}$ later, cell death was measured by flow cytometry using PI staining. (C) LN-229 cells and the four cell clones were treated with $2.5 \mu \mathrm{M}$ BV6. Then, $144 \mathrm{~h}$ later, cell death was measured by flow cytometry using PI staining. (B,C) Experiments were repeated at least three times; mean values \pm SD are shown. Differences in the SubG1 fraction between control and TMZ treatment (B) and between con and BV6 treatment (C) were statistically analyzed using Student's $t$-test (not labeled $=$ not significant, $\left.{ }^{* *} p<0.01,{ }^{* * *} p<0.001\right)$. 

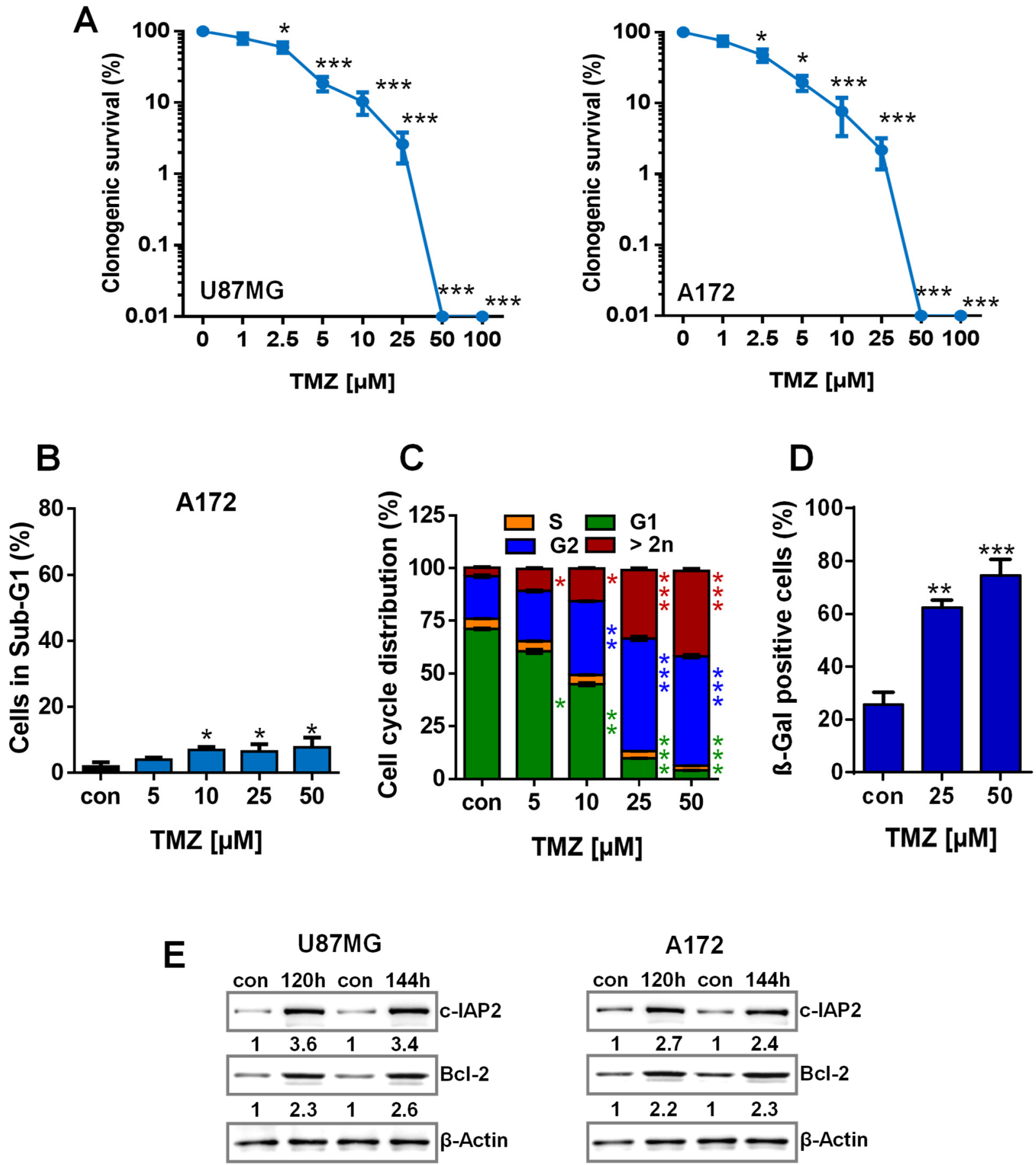

A172

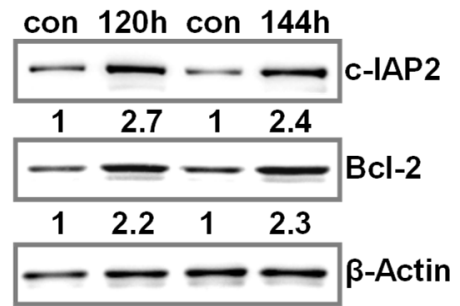

Figure A4. (A) Proliferation arrest and clonogenic survival was measured upon exposure up to $100 \mu \mathrm{M}$ TMZ by colony formation assay in U87MG and A172 cells. Cell death (B) and cell cycle distribution (C) were measured $144 \mathrm{~h}$ upon exposure to $50 \mu \mathrm{M}$ TMZ by flow cytometry using PI staining in A172 cells. (D) Senescence was measured by flow cytometry using SA- $\beta$-Gal staining $144 \mathrm{~h}$ after exposure to TMZ in A172 cells. (E) U87MG and A172 cells were treated with $50 \mu \mathrm{M}$ TMZ. Then, 120 and $144 \mathrm{~h}$ later, expression of c-IAP2 and Bcl-2 protein was measured by immunodetection. (A-D) Experiments were performed in triplicate, and differences between treatment and control were statistically analyzed using Student's $t$-test (not labeled $=$ not significant, ${ }^{*} p<0.1,{ }^{* *} p<0.01,{ }^{* * *} p<0.001$ ). 


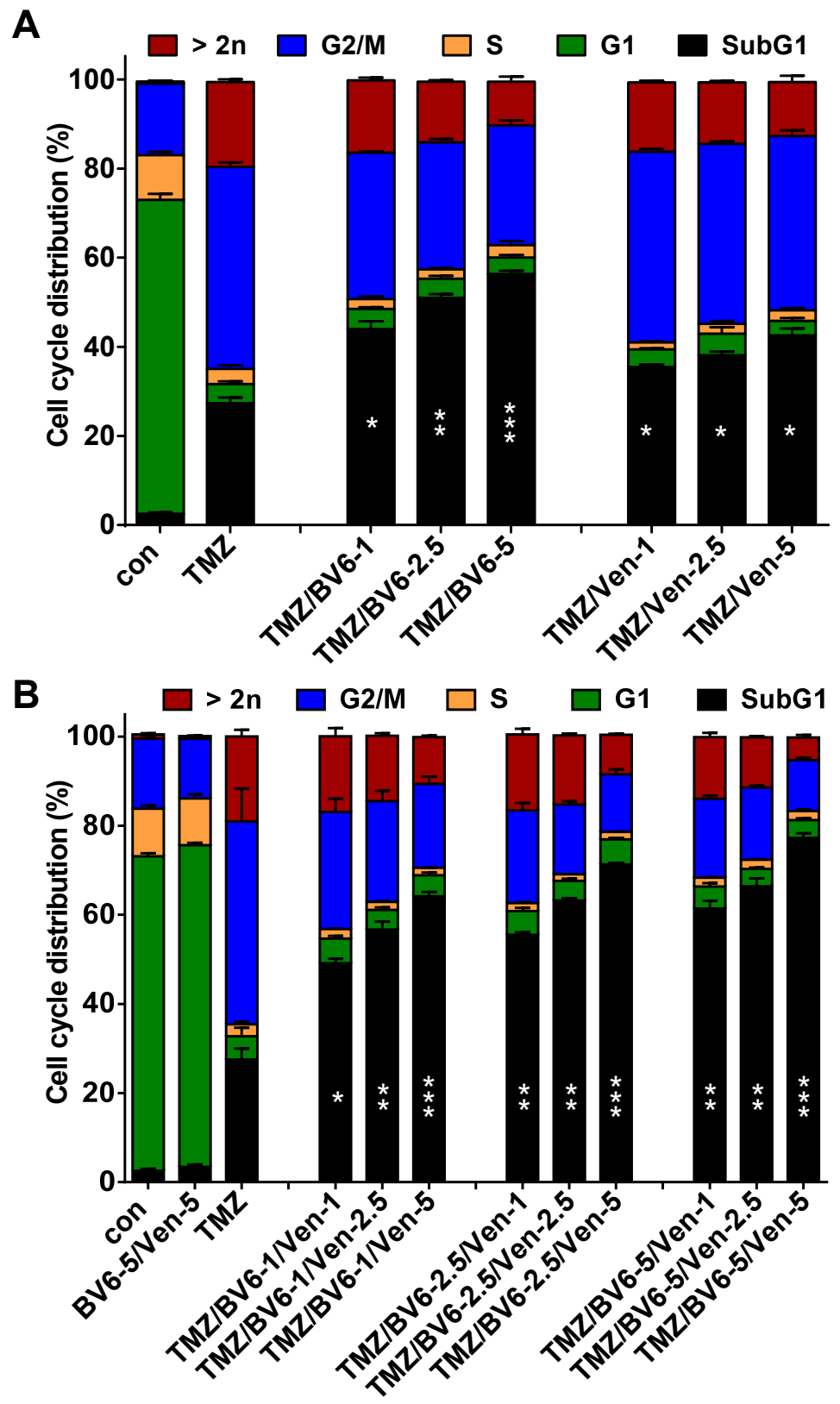

Figure A5. (A) A172 cells were treated with $50 \mu \mathrm{M}$ TMZ for $120 \mathrm{~h}$. Thereafter the medium was changed, and the cells were either further cultivated for an additional $120 \mathrm{~h}$ in the absence (TMZ) or the presence of different concentrations of BV6 or venetoclax (TMZ/inhibitor). As a control, cells were cultivated for $120 \mathrm{~h}$; thereafter, the medium was replaced, and the cells were further cultivated for $120 \mathrm{~h}$ (con). After a total of $240 \mathrm{~h}$, cell death and cell cycle distribution were measured by flow cytometry using PI staining. (B) A172 cells were treated with $50 \mu \mathrm{M}$ TMZ for $120 \mathrm{~h}$. Thereafter, the medium was changed, and the cells were either further cultivated for an additional $120 \mathrm{~h}$ in the absence (TMZ) or the presence of 1, 2.5, or $5 \mu \mathrm{M}$ BV6 combined with 1, 2.5, or $5 \mu \mathrm{M}$ venetoclax. As control, the cells were cultivated for $120 \mathrm{~h}$; thereafter, the medium was replaced, and the cells were further cultivated for $120 \mathrm{~h}$ in the absence (con) or presence of the inhibitors (5 $\mu \mathrm{M} \mathrm{BV6/}$ $5 \mu \mathrm{M}$ venetoclax). After a total of $240 \mathrm{~h}$, cell death and cell cycle distribution were measured by flow cytometry using PI staining. A/B experiments were repeated at least three times; mean values $\pm \mathrm{SD}$ are shown. Differences in the SubG1 fraction between inhibitor/TMZ treatment and TMZ were statistically analyzed using Student's $t$-test (not labeled $=$ not significant, ${ }^{*} p<0.1,{ }^{* *} p<0.01$, *** $p<0.001)$. 


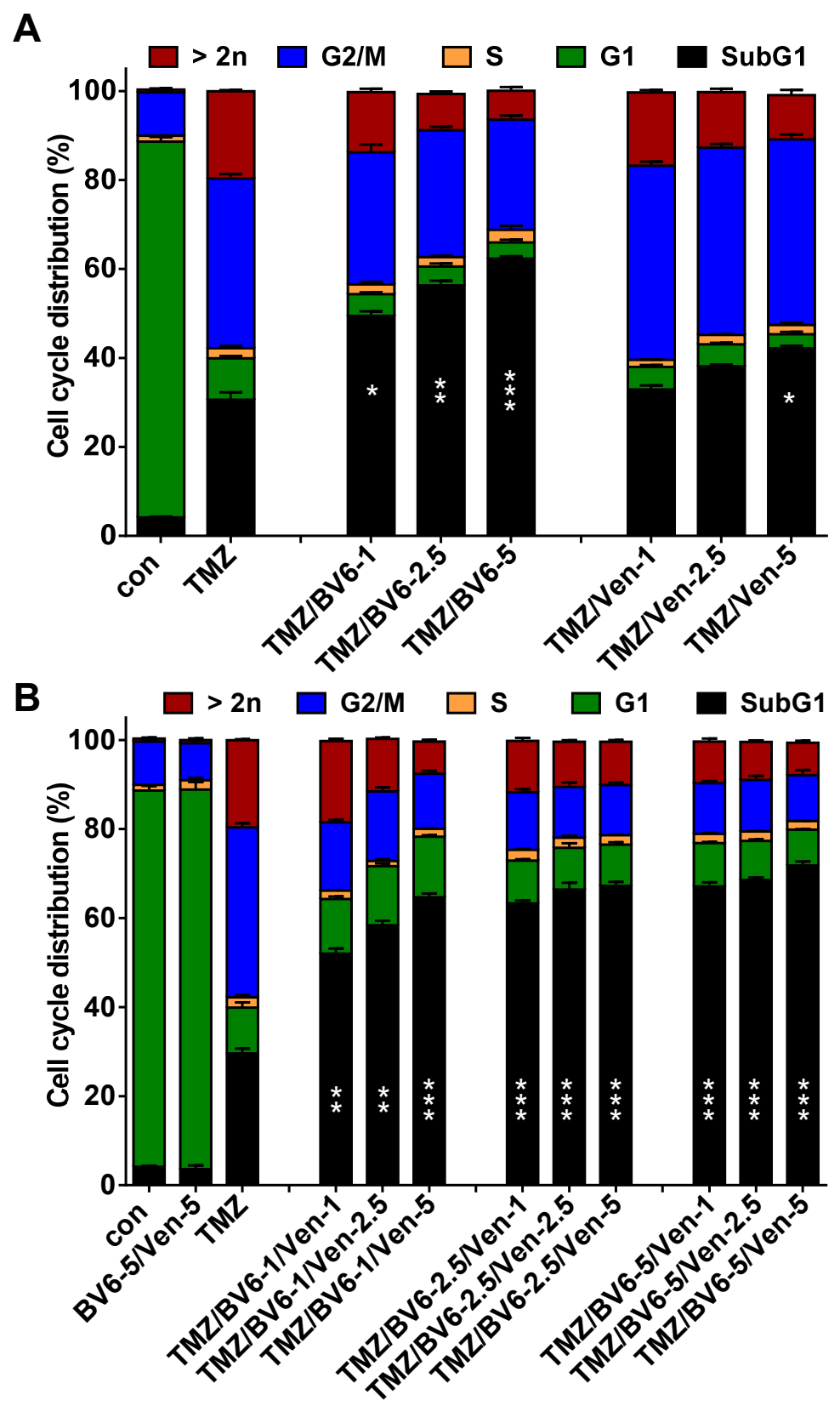

Figure A6. (A) U87MG cells were treated with $50 \mu \mathrm{M}$ TMZ for $120 \mathrm{~h}$. Thereafter, the medium was changed, and the cells were either further cultivated for an additional $120 \mathrm{~h}$ in the absence (TMZ) or the presence of different concentrations of BV6 or venetoclax (TMZ/inhibitor). As a control, cells were cultivated for $120 \mathrm{~h}$; thereafter, the medium was replaced, and the cells were further cultivated for $120 \mathrm{~h}$ (con). After a total of $240 \mathrm{~h}$, cell death and cell cycle distribution were measured by flow cytometry using PI staining. (B) U87MG cells were treated with $50 \mu \mathrm{M}$ TMZ for $120 \mathrm{~h}$. Thereafter, the medium was changed, and the cells were either further cultivated for an additional $120 \mathrm{~h}$ in the absence (TMZ) or the presence of $1,2.5$, or $5 \mu \mathrm{M}$ BV6 combined with $1,2.5$, or $5 \mu \mathrm{M}$ venetoclax. As a control, cells were cultivated for $120 \mathrm{~h}$; thereafter, the medium was replaced, and the cells were further cultivated for $120 \mathrm{~h}$ in the absence (con) or presence of the inhibitors (5 $\mu \mathrm{M} \mathrm{BV6/}$ $5 \mu \mathrm{M}$ venetoclax). After a total of $240 \mathrm{~h}$, cell death and cell cycle distribution were measured by flow cytometry using PI staining. A/B experiments were repeated at least three times; mean values \pm SD are shown. Differences in the SubG1 fraction between inhibitor/TMZ treatment and TMZ were statistically analyzed using Student's $t$-test (not labeled $=$ not significant, ${ }^{*} p<0.1,{ }^{* *} p<0.01$, $* * * 0<0.001)$ 


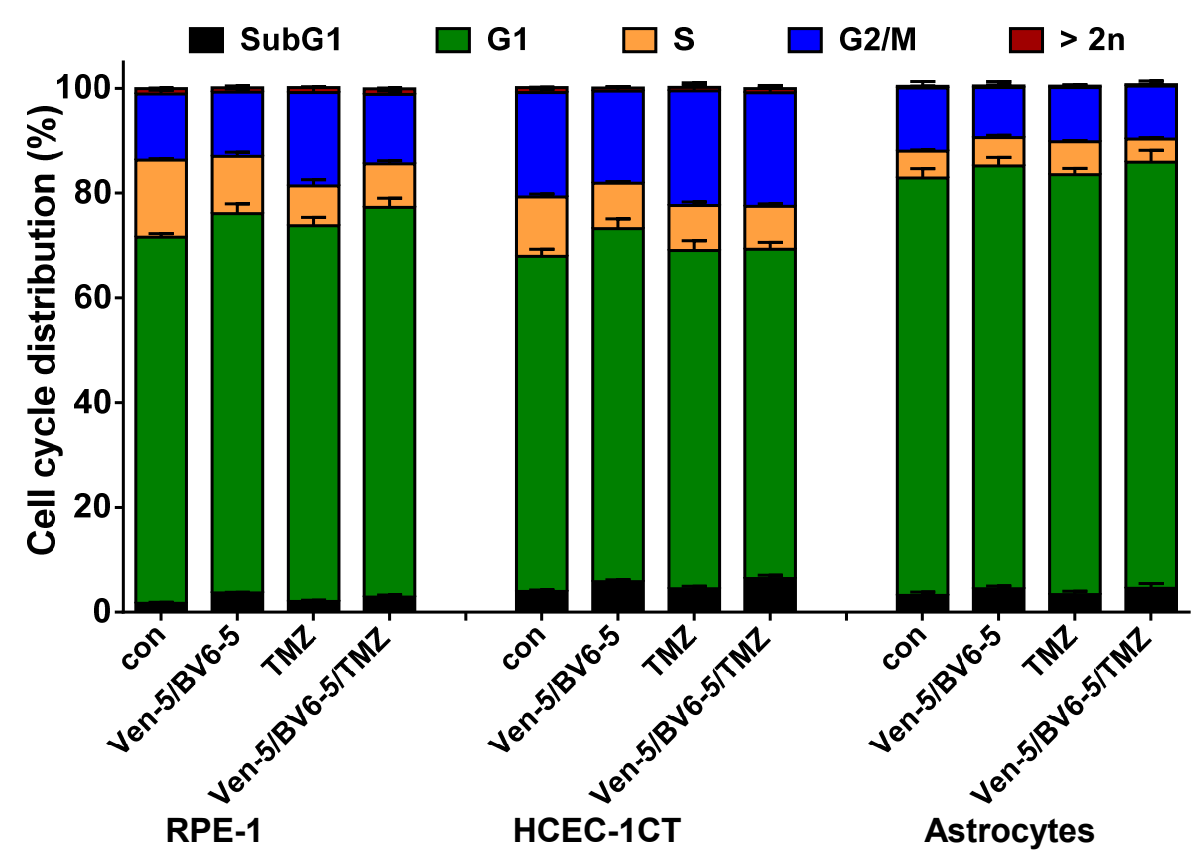

Figure A7. RPE-1, HCEC, and telomerase immortalized astrocytes were non-treated (con), treated with $50 \mu \mathrm{M}$ TMZ or $5 \mu \mathrm{M}$ BV $6+5 \mu \mathrm{M}$ venetoclax or $50 \mu \mathrm{M} \mathrm{TMZ}+5 \mu \mathrm{M}$ BV $6+5 \mu \mathrm{M}$ venetoclax. After a total of $120 \mathrm{~h}$, cell death and cell cycle distribution were measured by flow cytometry using PI staining. Experiments were repeated three times; mean values \pm SD are shown. Differences in the SubG1 were statistically analyzed using Student's $t$-test and were found to be not significant.
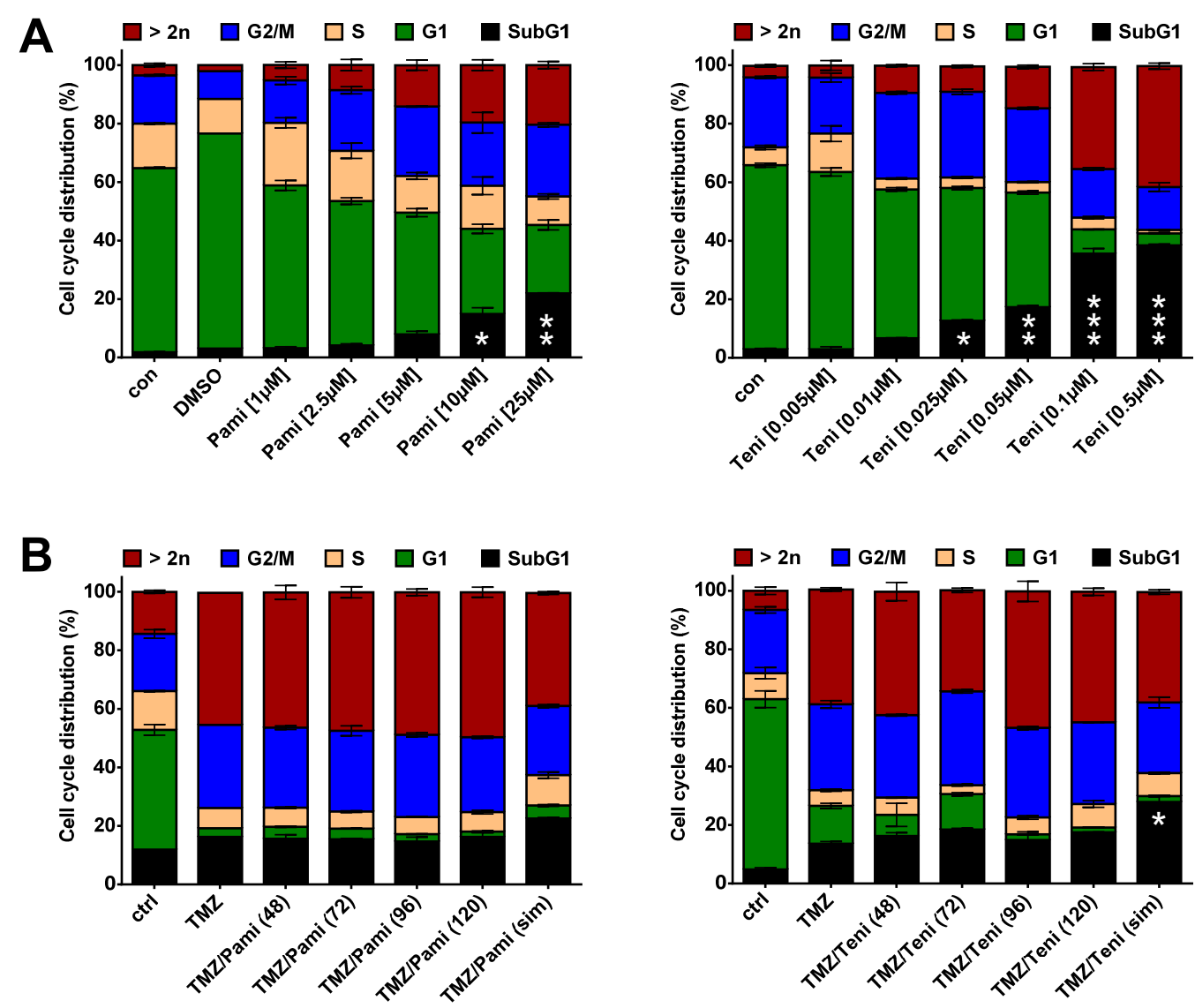

Figure A8. Cont. 

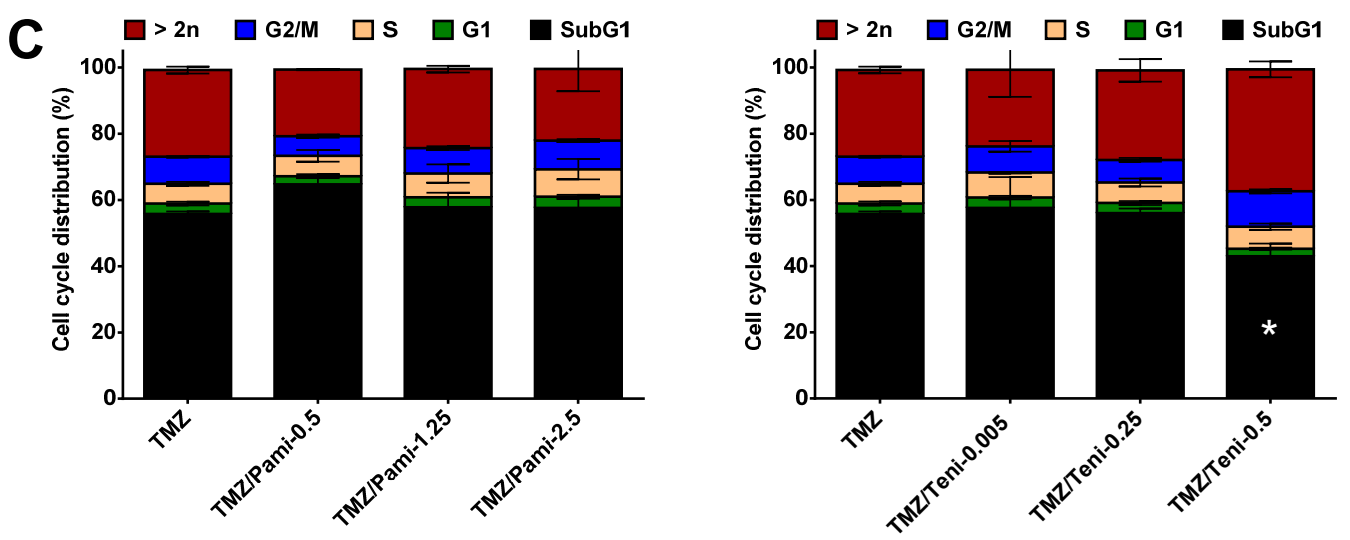

Figure A8. (A) LN-229 cells were treated with different concentrations of the topoisomerase II inhibitor teniposide (Teni) or the PARP inhibitor pamiparib (Pami). Cell death and cell cycle distribution was measured by flow cytometry using PI staining. Experiments were repeated at least three times; mean values \pm SD are shown. (B) LN-229 cells were either non-treated (con) or treated with $50 \mu \mathrm{M}$ TMZ for $120 \mathrm{~h}$ (TMZ). In addition, $0.025 \mu \mathrm{M}$ teniposide or $2.5 \mu \mathrm{M}$ pamiparib were added either simultaneously with TMZ (sim) or 48, 72, or $120 \mathrm{~h}$ after TMZ exposure. Cell death and cell cycle distribution was measured by flow cytometry using PI staining in LN-229 cells. Experiments were repeated at least three times; mean values \pm SD are shown. (C) LN-229 cells were treated with $50 \mu \mathrm{M}$ TMZ for $120 \mathrm{~h}$. Thereafter the medium was changed, and cells were again treated with $50 \mu \mathrm{M}$ TMZ for $120 \mathrm{~h}$ (TMZ) or with TMZ combined with different concentrations of teniposide or pamiparib. (A-C) Experiments were performed in triplicate, and differences of cells in SubG1 between Pami or Teni vs. control (A), as well as TMZ/Pami or TMZ/Teni vs. TMZ alone (A,B) were statistically analyzed using Student's $t$-test (not labeled $=$ not significant, ${ }^{*} p<0.1,{ }^{* *} p<0.01,{ }^{* * *} p<0.001$ ).
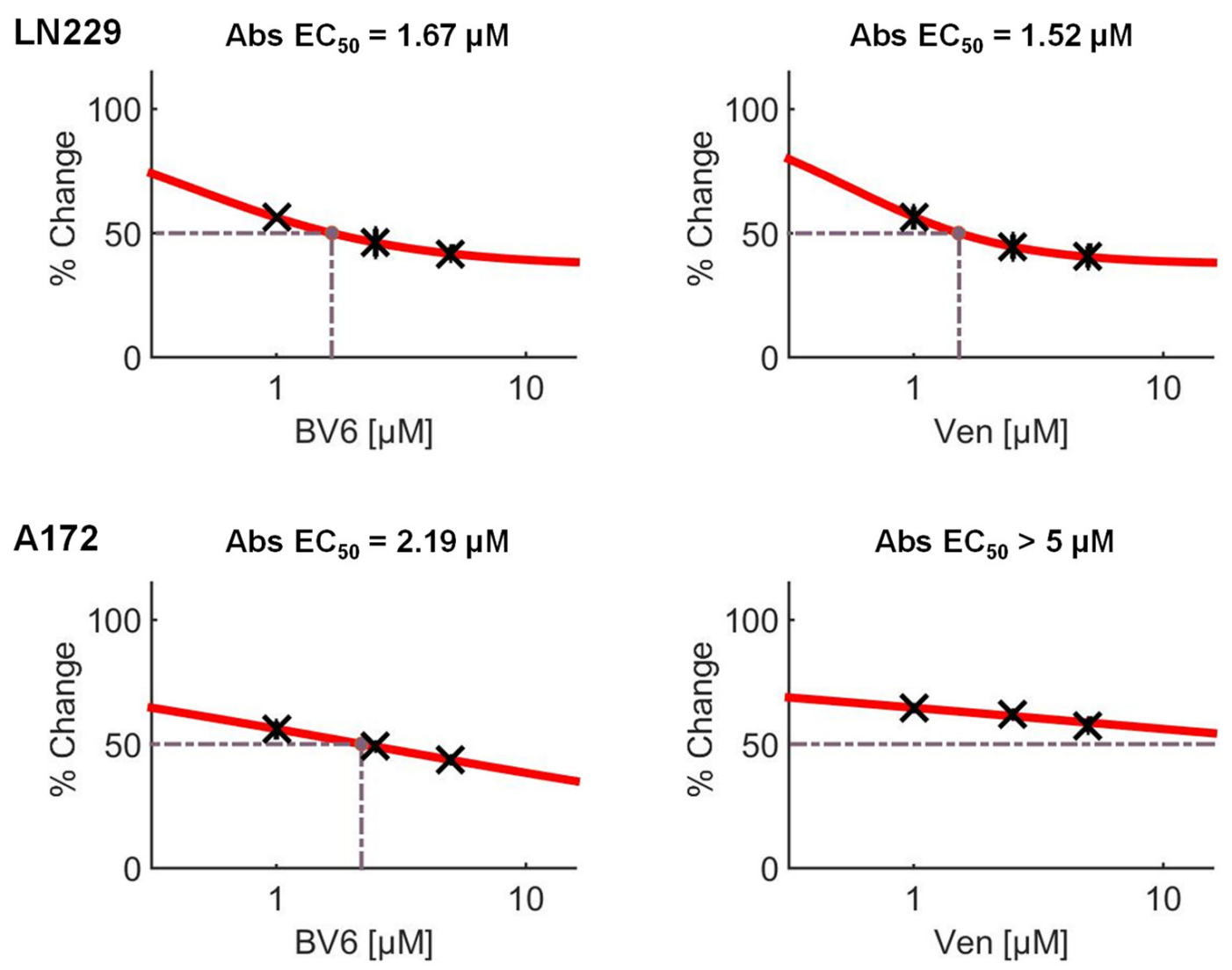

Figure A9. Cont. 

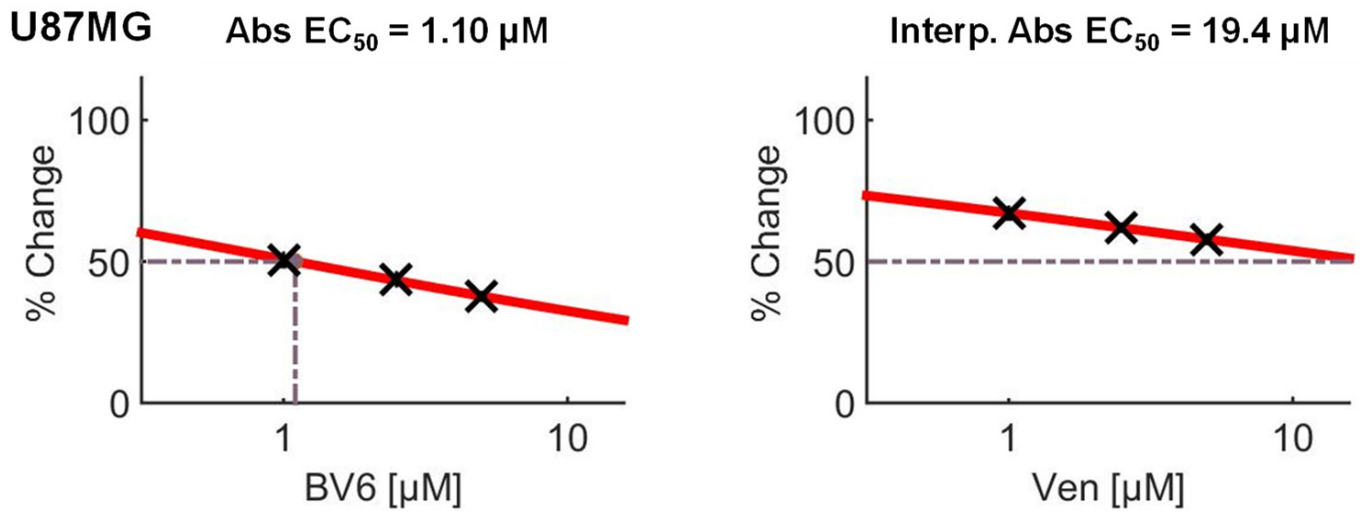

Figure A9. Toxicity data presented in Figures 4A, A5A and A6A were used to calculate $\mathrm{EC}_{50}$ of BV6 and venetoclax using Combenefit software.

\section{References}

1. Wen, P.Y.; Kesari, S. Malignant gliomas in adults. N. Engl. J. Med. 2008, 359, 492-507. [CrossRef] [PubMed]

2. Stupp, R.; Mason, W.P.; van den Bent, M.J.; Weller, M.; Fisher, B.; Taphoorn, M.J.; Belanger, K.; Brandes, A.A.; Marosi, C.; Bogdahn, U.; et al. Radiotherapy plus concomitant and adjuvant temozolomide for glioblastoma. N. Engl. J. Med. 2005, 352, 987-996. [CrossRef]

3. Stupp, R.; Hegi, M.E.; Mason, W.P.; van den Bent, M.J.; Taphoorn, M.J.; Janzer, R.C.; Ludwin, S.K.; Allgeier, A.; Fisher, B.; Belanger, K.; et al. Effects of radiotherapy with concomitant and adjuvant temozolomide versus radiotherapy alone on survival in glioblastoma in a randomised phase III study: 5-year analysis of the EORTC-NCIC trial. Lancet. Oncol. 2009, 10, 459-466. [CrossRef]

4. Kaina, B.; Christmann, M. DNA repair in resistance to alkylating anticancer drugs. Int. J. Clin. Pharm. 2002, 40, 354-367. [CrossRef] [PubMed]

5. Christmann, M.; Diesler, K.; Majhen, D.; Steigerwald, C.; Berte, N.; Freund, H.; Stojanovic, N.; Kaina, B.; Osmak, M.; AmbriovicRistov, A.; et al. Integrin alphaVbeta3 silencing sensitizes malignant glioma cells to temozolomide by suppression of homologous recombination repair. Oncotarget 2017, 8, 27754-27771. [CrossRef]

6. Tomicic, M.T.; Meise, R.; Aasland, D.; Berte, N.; Kitzinger, R.; Kramer, O.H.; Kaina, B.; Christmann, M. Apoptosis induced by temozolomide and nimustine in glioblastoma cells is supported by JNK/c-Jun-mediated induction of the BH3-only protein BIM. Oncotarget 2015, 6, 33755-33768. [CrossRef] [PubMed]

7. Knizhnik, A.V.; Roos, W.P.; Nikolova, T.; Quiros, S.; Tomaszowski, K.H.; Christmann, M.; Kaina, B. Survival and death strategies in glioma cells: Autophagy, senescence and apoptosis triggered by a single type of temozolomide-induced DNA damage. PLoS ONE 2013, 8, e55665. [CrossRef]

8. Aasland, D.; Gotzinger, L.; Hauck, L.; Berte, N.; Meyer, J.; Effenberger, M.; Schneider, S.; Reuber, E.E.; Roos, W.P.; Tomicic, M.T.; et al. Temozolomide Induces Senescence and Repression of DNA Repair Pathways in Glioblastoma Cells via Activation of ATR-CHK1, p21, and NF-kappaB. Cancer Res. 2019, 79, 99-113. [CrossRef] [PubMed]

9. Hayflick, L. The Limited in Vitro Lifetime of Human Diploid Cell Strains. Exp. Cell Res. 1965, 37, 614-636. [CrossRef]

10. D'Adda di Fagagna, F. Living on a break: Cellular senescence as a DNA-damage response. Nat. Rev. Cancer 2008, 8, 512-522. [CrossRef]

11. Muller, M. Cellular senescence: Molecular mechanisms, in vivo significance, and redox considerations. Antioxid. Redox Signal. 2009, 11, 59-98. [CrossRef] [PubMed]

12. Fridman, A.L.; Tainsky, M.A. Critical pathways in cellular senescence and immortalization revealed by gene expression profiling. Oncogene 2008, 27, 5975-5987. [CrossRef]

13. Cichowski, K.; Hahn, W.C. Unexpected pieces to the senescence puzzle. Cell 2008, 133, 958-961. [CrossRef] [PubMed]

14. Velarde, M.C.; Demaria, M.; Campisi, J. Senescent cells and their secretory phenotype as targets for cancer therapy. Interdiscip. Top. Gerontol. 2013, 38, 17-27. [CrossRef] [PubMed]

15. Coppe, J.P.; Desprez, P.Y.; Krtolica, A.; Campisi, J. The senescence-associated secretory phenotype: The dark side of tumor suppression. Annu. Rev. Pathol. 2010, 5, 99-118. [CrossRef]

16. Coppe, J.P.; Patil, C.K.; Rodier, F.; Sun, Y.; Munoz, D.P.; Goldstein, J.; Nelson, P.S.; Desprez, P.Y.; Campisi, J. Senescence-associated secretory phenotypes reveal cell-nonautonomous functions of oncogenic RAS and the p53 tumor suppressor. PLoS Biol. 2008, 6, 2853-2868. [CrossRef]

17. Kuilman, T.; Michaloglou, C.; Vredeveld, L.C.; Douma, S.; van Doorn, R.; Desmet, C.J.; Aarden, L.A.; Mooi, W.J.; Peeper, D.S. Oncogene-induced senescence relayed by an interleukin-dependent inflammatory network. Cell 2008, 133, 1019-1031. [CrossRef]

18. Acosta, J.C.; O'Loghlen, A.; Banito, A.; Guijarro, M.V.; Augert, A.; Raguz, S.; Fumagalli, M.; Da Costa, M.; Brown, C.; Popov, N.; et al. Chemokine signaling via the CXCR2 receptor reinforces senescence. Cell 2008, 133, 1006-1018. [CrossRef] 
19. Kang, T.W.; Yevsa, T.; Woller, N.; Hoenicke, L.; Wuestefeld, T.; Dauch, D.; Hohmeyer, A.; Gereke, M.; Rudalska, R.; Potapova, A.; et al. Senescence surveillance of pre-malignant hepatocytes limits liver cancer development. Nature 2011, 479, 547-551. [CrossRef] [PubMed]

20. Xue, W.; Zender, L.; Miething, C.; Dickins, R.A.; Hernando, E.; Krizhanovsky, V.; Cordon-Cardo, C.; Lowe, S.W. Senescence and tumour clearance is triggered by p53 restoration in murine liver carcinomas. Nature 2007, 445, 656-660. [CrossRef]

21. Bavik, C.; Coleman, I.; Dean, J.P.; Knudsen, B.; Plymate, S.; Nelson, P.S. The gene expression program of prostate fibroblast senescence modulates neoplastic epithelial cell proliferation through paracrine mechanisms. Cancer Res. 2006, 66, 794-802. [CrossRef]

22. Parrinello, S.; Coppe, J.P.; Krtolica, A.; Campisi, J. Stromal-epithelial interactions in aging and cancer: Senescent fibroblasts alter epithelial cell differentiation. J. Cell Sci. 2005, 118, 485-496. [CrossRef]

23. Laberge, R.M.; Awad, P.; Campisi, J.; Desprez, P.Y. Epithelial-mesenchymal transition induced by senescent fibroblasts. Cancer Microenviron. 2012, 5, 39-44. [CrossRef]

24. Krtolica, A.; Parrinello, S.; Lockett, S.; Desprez, P.Y.; Campisi, J. Senescent fibroblasts promote epithelial cell growth and tumorigenesis: A link between cancer and aging. Proc. Natl. Acad. Sci. USA 2001, 98, 12072-12077. [CrossRef]

25. Liu, D.; Hornsby, P.J. Senescent human fibroblasts increase the early growth of xenograft tumors via matrix metalloproteinase secretion. Cancer Res. 2007, 67, 3117-3126. [CrossRef] [PubMed]

26. Sage, J.; Miller, A.L.; Perez-Mancera, P.A.; Wysocki, J.M.; Jacks, T. Acute mutation of retinoblastoma gene function is sufficient for cell cycle re-entry. Nature 2003, 424, 223-228. [CrossRef] [PubMed]

27. Beausejour, C.M.; Krtolica, A.; Galimi, F.; Narita, M.; Lowe, S.W.; Yaswen, P.; Campisi, J. Reversal of human cellular senescence: Roles of the p53 and p16 pathways. EMBO J. 2003, 22, 4212-4222. [CrossRef]

28. Michishita, E.; Nakabayashi, K.; Ogino, H.; Suzuki, T.; Fujii, M.; Ayusawa, D. DNA topoisomerase inhibitors induce reversible senescence in normal human fibroblasts. Biochem. Biophys. Res. Commun. 1998, 253, 667-671. [CrossRef]

29. Chitikova, Z.V.; Gordeev, S.A.; Bykova, T.V.; Zubova, S.G.; Pospelov, V.A.; Pospelova, T.V. Sustained activation of DNA damage response in irradiated apoptosis-resistant cells induces reversible senescence associated with mTOR downregulation and expression of stem cell markers. Cell Cycle 2014, 13, 1424-1439. [CrossRef] [PubMed]

30. Lee, S.; Schmitt, C.A. The dynamic nature of senescence in cancer. Nat. Cell Biol. 2019, 21, 94-101. [CrossRef]

31. Yu, Y.; Schleich, K.; Yue, B.; Ji, S.; Lohneis, P.; Kemper, K.; Silvis, M.R.; Qutob, N.; van Rooijen, E.; Werner-Klein, M.; et al. Targeting the Senescence-Overriding Cooperative Activity of Structurally Unrelated H3K9 Demethylases in Melanoma. Cancer Cell 2018, 33, 322-336.e328. [CrossRef]

32. Milanovic, M.; Fan, D.N.Y.; Belenki, D.; Dabritz, J.H.M.; Zhao, Z.; Yu, Y.; Dorr, J.R.; Dimitrova, L.; Lenze, D.; Monteiro Barbosa, I.A.; et al. Senescence-associated reprogramming promotes cancer stemness. Nature 2018, 553, 96-100. [CrossRef] [PubMed]

33. Debacq-Chainiaux, F.; Erusalimsky, J.D.; Campisi, J.; Toussaint, O. Protocols to detect senescence-associated beta-galactosidase (SA-betagal) activity, a biomarker of senescent cells in culture and in vivo. Nat. Protoc. 2009, 4, 1798-1806. [CrossRef]

34. Leikam, C.; Hufnagel, A.L.; Otto, C.; Murphy, D.J.; Muhling, B.; Kneitz, S.; Nanda, I.; Schmid, M.; Wagner, T.U.; Haferkamp, S.; et al. In vitro evidence for senescent multinucleated melanocytes as a source for tumor-initiating cells. Cell Death Dis. 2015, 6, e1711. [CrossRef] [PubMed]

35. Tomicic, M.T.; Christmann, M. Targeting anticancer drug-induced senescence in glioblastoma therapy. Oncotarget 2018, 9 , 37466-37467. [CrossRef] [PubMed]

36. Kirkland, J.L.; Tchkonia, T.; Zhu, Y.; Niedernhofer, L.J.; Robbins, P.D. The Clinical Potential of Senolytic Drugs. J. Am. Geriatr. Soc. 2017, 65, 2297-2301. [CrossRef]

37. Kirkland, J.L.; Tchkonia, T. Cellular Senescence: A Translational Perspective. EBioMedicine 2017, 21, 21-28. [CrossRef] [PubMed]

38. Turcan, S.; Rohle, D.; Goenka, A.; Walsh, L.A.; Fang, F.; Yilmaz, E.; Campos, C.; Fabius, A.W.; Lu, C.; Ward, P.S.; et al. IDH1 mutation is sufficient to establish the glioma hypermethylator phenotype. Nature 2012, 483, 479-483. [CrossRef]

39. Roig, A.I.; Eskiocak, U.; Hight, S.K.; Kim, S.B.; Delgado, O.; Souza, R.F.; Spechler, S.J.; Wright, W.E.; Shay, J.W. Immortalized epithelial cells derived from human colon biopsies express stem cell markers and differentiate in vitro. Gastroenterology 2010, 138, 1012-1021.e5. [CrossRef]

40. Tomicic, M.T.; Krämer, F.; Nguyen, A.; Schwarzenbach, C.; Christmann, M. Oxaliplatin-Induced Senescence in Colorectal Cancer Cells Depends on p14ARF-Mediated Sustained p53 Activation. Cancers 2021, 13, 2019. [CrossRef]

41. Christmann, M.; Kaina, B. Nuclear translocation of mismatch repair proteins MSH2 and MSH6 as a response of cells to alkylating agents. J. Biol. Chem. 2000, 275, 36256-36262. [CrossRef] [PubMed]

42. Di Veroli, G.Y.; Fornari, C.; Wang, D.; Mollard, S.; Bramhall, J.L.; Richards, F.M.; Jodrell, D.I. Combenefit: An interactive platform for the analysis and visualization of drug combinations. Bioinformatics 2016, 32, 2866-2868. [CrossRef] [PubMed]

43. He, Y.; Kaina, B. Are There Thresholds in Glioblastoma Cell Death Responses Triggered by Temozolomide? Int. J. Mol. Sci. 2019, 20, 1562. [CrossRef] [PubMed]

44. Stratenwerth, B.; Geisen, S.M.; He, Y.; Beltzig, L.; Sturla, S.J.; Kaina, B. Molecular dosimetry of temozolomide: Quantification of critical lesions, correlation to cell death responses and threshold doses. Mol. Cancer Ther. 2021, in press. [CrossRef] [PubMed]

45. Eich, M.; Roos, W.P.; Nikolova, T.; Kaina, B. Contribution of ATM and ATR to the resistance of glioblastoma and malignant melanoma cells to the methylating anticancer drug temozolomide. Mol. Cancer Ther. 2013, 12, 2529-2540. [CrossRef] [PubMed]

46. Quiros, S.; Roos, W.P.; Kaina, B. Processing of O6-methylguanine into DNA double-strand breaks requires two rounds of replication whereas apoptosis is also induced in subsequent cell cycles. Cell Cycle 2010, 9, 168-178. [CrossRef] 
47. Li, W.; Qin, L.; Feng, R.; Hu, G.; Sun, H.; He, Y.; Zhang, R. Emerging senolytic agents derived from natural products. Mech. Ageing Dev. 2019, 181, 1-6. [CrossRef] [PubMed]

48. Reich, T.R.; Schwarzenbach, C.; Vilar, J.B.; Unger, S.; Muhlhausler, F.; Nikolova, T.; Poplawski, A.; Baymaz, H.I.; Beli, P.; Christmann, M.; et al. Localization matters: Nuclear-trapped Survivin sensitizes glioblastoma cells to temozolomide by elevating cellular senescence and impairing homologous recombination. Cell. Mol. Life Sci. CMLS 2021, 78, 5587-5604. [CrossRef]

49. Kuffer, C.; Kuznetsova, A.Y.; Storchova, Z. Abnormal mitosis triggers p53-dependent cell cycle arrest in human tetraploid cells. Chromosoma 2013, 122, 305-318. [CrossRef]

50. Walen, K.H. Genetic stability of senescence reverted cells: Genome reduction division of polyploidy cells, aneuploidy and neoplasia. Cell Cycle 2008, 7, 1623-1629. [CrossRef]

51. Mosieniak, G.; Sikora, E. Polyploidy: The link between senescence and cancer. Curr. Pharm. Des. 2010, 16, 734-740. [CrossRef]

52. Kirkland, J.L.; Tchkonia, T. Senolytic drugs: From discovery to translation. J. Intern. Med. 2020, 288, 518-536. [CrossRef]

53. Wang, E. Senescent human fibroblasts resist programmed cell death, and failure to suppress bcl2 is involved. Cancer Res. 1995, 55, 2284-2292. [PubMed]

54. Zhu, Y.; Tchkonia, T.; Pirtskhalava, T.; Gower, A.C.; Ding, H.; Giorgadze, N.; Palmer, A.K.; Ikeno, Y.; Hubbard, G.B.; Lenburg, M.; et al. The Achilles' heel of senescent cells: From transcriptome to senolytic drugs. Aging Cell 2015, 14, 644-658. [CrossRef]

55. Shahbandi, A.; Rao, S.G.; Anderson, A.Y.; Frey, W.D.; Olayiwola, J.O.; Ungerleider, N.A.; Jackson, J.G. BH3 mimetics selectively eliminate chemotherapy-induced senescent cells and improve response in TP53 wild-type breast cancer. Cell Death Differ. 2020, 27, 3097-3116. [CrossRef] [PubMed]

56. Malaquin, N.; Vancayseele, A.; Gilbert, S.; Antenor-Habazac, L.; Olivier, M.A.; Ait Ali Brahem, Z.; Saad, F.; Delouya, G.; Rodier, F. DNA Damage- But Not Enzalutamide-Induced Senescence in Prostate Cancer Promotes Senolytic Bcl-xL Inhibitor Sensitivity. Cells 2020, 9, 1593. [CrossRef] [PubMed]

57. Marschall, V.; Fulda, S. Smac mimetic-induced upregulation of interferon-beta sensitizes glioblastoma to temozolomide-induced cell death. Cell Death Dis. 2015, 6, e1888. [CrossRef] [PubMed]

58. Wang, D.; Berglund, A.; Kenchappa, R.S.; Forsyth, P.A.; Mule, J.J.; Etame, A.B. BIRC3 is a novel driver of therapeutic resistance in Glioblastoma. Sci. Rep. 2016, 6, 21710. [CrossRef]

59. Tomicic, M.T. Replica to the Opinion Letter regarding the article "Sensitization of colorectal cancer cells to irinotecan by the Survivin inhibitor LLP3 depends on XAF1 proficiency in the context of mutated p53" (Arch Toxicol https://doi.org/10.1007/s0 0204-018-240-x). Arch. Toxicol. 2018, 92, 3243-3244. [CrossRef]

60. Steigerwald, C.; Rasenberger, B.; Christmann, M.; Tomicic, M.T. Sensitization of colorectal cancer cells to irinotecan by the Survivin inhibitor LLP3 depends on XAF1 proficiency in the context of mutated p53. Arch. Toxicol. 2018, 92, 2645-2648. [CrossRef]

61. Tomicic, M.T.; Steigerwald, C.; Rasenberger, B.; Brozovic, A.; Christmann, M. Functional mismatch repair and inactive p53 drive sensitization of colorectal cancer cells to irinotecan via the IAP antagonist BV6. Arch. Toxicol. 2019, 93, $2265-2277$. [CrossRef] [PubMed]

62. Stepanenko, A.A.; Chekhonin, V.P. On the Critical Issues in Temozolomide Research in Glioblastoma: Clinically Relevant Concentrations and MGMT-independent Resistance. Biomedicines 2019, 7, 92. [CrossRef] [PubMed]

63. Hammond, L.A.; Eckardt, J.R.; Baker, S.D.; Eckhardt, S.G.; Dugan, M.; Forral, K.; Reidenberg, P.; Statkevich, P.; Weiss, G.R.; Rinaldi, D.A.; et al. Phase I and pharmacokinetic study of temozolomide on a daily-for-5-days schedule in patients with advanced solid malignancies. J. Clin. Oncol. 1999, 17, 2604-2613. [CrossRef]

64. Rosso, L.; Brock, C.S.; Gallo, J.M.; Saleem, A.; Price, P.M.; Turkheimer, F.E.; Aboagye, E.O. A N. model for prediction of drug distribution in tumor and normal tissues: Pharmacokinetics of temozolomide in glioma patients. Cancer Res. 2009, 69, 120-127. [CrossRef] [PubMed]

65. Ostermann, S.; Csajka, C.; Buclin, T.; Leyvraz, S.; Lejeune, F.; Decosterd, L.A.; Stupp, R. Plasma and cerebrospinal fluid population pharmacokinetics of temozolomide in malignant glioma patients. Clin. Cancer Res. Off. J. Am. Assoc. Cancer Res. 2004, 10, 3728-3736. [CrossRef]

66. Portnow, J.; Badie, B.; Chen, M.; Liu, A.; Blanchard, S.; Synold, T.W. The neuropharmacokinetics of temozolomide in patients with resectable brain tumors: Potential implications for the current approach to chemoradiation. Clin. Cancer Res. Off. J. Am. Assoc. Cancer Res. 2009, 15, 7092-7098. [CrossRef]

67. Jackson, S.; Weingart, J.; Nduom, E.K.; Harfi, T.T.; George, R.T.; McAreavey, D.; Ye, X.; Anders, N.M.; Peer, C.; Figg, W.D.; et al. The effect of an adenosine A2A agonist on intra-tumoral concentrations of temozolomide in patients with recurrent glioblastoma. Fluids Barriers CNS 2018, 15, 2. [CrossRef] [PubMed]

68. Hermisson, M.; Klumpp, A.; Wick, W.; Wischhusen, J.; Nagel, G.; Roos, W.; Kaina, B.; Weller, M. O6-methylguanine DNA methyltransferase and p53 status predict temozolomide sensitivity in human malignant glioma cells. J. Neurochem. 2006, 96, 766-776. [CrossRef]

69. Strobel, H.; Baisch, T.; Fitzel, R.; Schilberg, K.; Siegelin, M.D.; Karpel-Massler, G.; Debatin, K.M.; Westhoff, M.A. Temozolomide and Other Alkylating Agents in Glioblastoma Therapy. Biomedicines 2019, 7, 69. [CrossRef]

70. D’Alessandris, Q.G.; Biffoni, M.; Martini, M.; Runci, D.; Buccarelli, M.; Cenci, T.; Signore, M.; Stancato, L.; Olivi, A.; De Maria, R.; et al. The clinical value of patient-derived glioblastoma tumorspheres in predicting treatment response. Neuro Oncol. 2017, 19, 1097-1108. [CrossRef] 
71. Villalva, C.; Cortes, U.; Wager, M.; Tourani, J.M.; Rivet, P.; Marquant, C.; Martin, S.; Turhan, A.G.; Karayan-Tapon, L. O6Methylguanine-methyltransferase (MGMT) promoter methylation status in glioma stem-like cells is correlated to temozolomide sensitivity under differentiation-promoting conditions. Int. J. Mol. Sci. 2012, 13, 6983-6994. [CrossRef] [PubMed]

72. Patel, M.; McCully, C.; Godwin, K.; Balis, F.M. Plasma and cerebrospinal fluid pharmacokinetics of intravenous temozolomide in non-human primates. J. Neuro Oncol. 2003, 61, 203-207. [CrossRef] [PubMed] 